\title{
THE EDAPHIC FACTOR AND PATTERNS OF VARIATION IN LASTHENIA CALIFORNICA (ASTERACEAE) ${ }^{1}$
}

\author{
Nishanta RAJAKARUNA AND BRUCE A. BOHM²
}

Department of Botany, University of British Columbia, Vancouver, British Columbia, Canada V6T 1Z4

\begin{abstract}
Transectional studies of Lasthenia californica in the Jasper Ridge Biological Preserve (Stanford University) have documented the existence of two races (A and C) based upon flavonoid chemistry, achene morphology, allozymes, and flowering time differences. The two races coexist on a serpentine outcrop and have maintained a sharply defined pattern of distribution for a period of at least $15 \mathrm{yr}$. The present study has revealed significant differences in the physical and chemical features of the soils harboring the two races. Soils at the lower ends of the transects, where race A plants grow, have higher $\mathrm{pH}$, cation exchange capacity, relative water content, total ionic strength, percentage clay, and sodium and magnesium concentrations than do soils harboring race $\mathrm{C}$ plants at the upper ends of the transects. Soils supporting race $\mathrm{C}$ plants have higher calcium, potassium, and nickel concentrations and higher calcium:magnesium ratios. Plant tissue concentrations of ions were also significantly different in the two races. Race A plants accumulated sodium to concentrations three times those observed with race $\mathrm{C}$ plants. Plants from an additional 22 sites gave very similar results. Greenhouse studies indicated that the two races from Jasper Ridge show differential responses to ridge-top and ridge-bottom soils. Race A achenes germinated, grew to maturity, and set seed about equally in the two soils. Race C achenes germinated in both types of soils but showed significantly poorer growth and absolutely no flowering when found in the soils of race A plants. Differential responses to edaphic conditions on the ridge may contribute to the pattern of distribution observed over the years. It is suggested that race A plants are more tolerant of edaphic stress than race $\mathrm{C}$ plants and that physiological specialization may contribute to the present distribution of the two races throughout the species' range. It is not yet possible to state which is the more significant factor in driving this specialization, the chemistry of the soil or its physical characteristics, or whether there is interaction between the two. This is the first study to present evidence for soil/plant variation within a serpentine site. The linking of sodium levels to racial differentiation within the serpentine habitat is also a new discovery.
\end{abstract}

Key words: Asteraceae; edaphic races; Lasthenia; serpentine; sodium; soil chemistry; trace metals; water stress.

Within a given climatic region, growth of vegetation is mainly determined by the character of the parent material, whether limestone, igneous rock, sand deposit or clayey shale.

Hans Jenny (1941)

Plants with unusual or localized distribution patterns have always fascinated botanists. The study of such plants has provided much valuable information on the history and evolution of certain regions and their floras. Further, these systems often provide excellent opportunities to investigate aspects of evolutionary ecology and population dynamics characterizing these plant populations. The study described in this paper involves an ex-

\footnotetext{
${ }^{1}$ Manuscript received 15 October 1998; revision accepted 27 May 1999

The authors thank the Natural Sciences and Engineering Research Council (Canada) for support of this study; the administrative staff of the Jasper Ridge Biological Preserve of Stanford University for allowing us to collect plant and soil samples and for providing accommodations and laboratory facilities during our extended studies in the Preserve; Ji Yong Yang, Lesley R. Bohm, Binney Girdler, and Nona Chiariello for assistance in the field; Anh-Toan Tran for technical assistance with the ICP and AA analyses; Tony Glass and Jeannette Whitton for useful comments and review of the manuscript; Les Lavkulich and Tim Ballard for providing much appreciated guidance and access to the soil chemistry laboratory facilities; and Gary Bradfield and Jack Maze for advice on statistical analyses. This work constitutes part of the Master of Science dissertation of the first-named author who thanks the University of British Columbia for the award of a University Graduate Fellowship.

${ }^{2}$ Author for correspondence (e-mail: bohm@unixg.ubc.ca).
}

amination of such a system: the influence of the edaphic factor on Lasthenia californica DC. ex Lindley (Asteraceae: Helenieae) (Karis and Ryding, 1994) throughout much of its range in western North America.

Lasthenia californica is the most widely distributed of the 17 species that comprise this mostly Californian genus (one species, L. kunthii, occurs in Chile). This obligatory outcrossing, spring annual ranges from south-central Oregon throughout California, from the foothills of the Sierra Nevada to the coast, east into Arizona, and in northern Baja California. The distribution of the species may be limited by its preference for a Mediterranean-type climate, characterized by mild, wet winters and long, hot, dry summers. Lasthenia californica shows a high degree of morphological, cytological (Ornduff, 1966), and biochemical diversity (Bohm, Saleh, and Ornduff, 1974; Bohm et al., 1989; Desrochers and Bohm, 1993, 1995). Ornduff (1966) considered it to be the most variable taxon in the genus.

The species has wide ecological tolerance: it can be found on coastal bluffs, in open grasslands, oak woodlands, alkali flats, chaparral, pastures, along roadsides, in desert habitats, and on serpentine outcrops. It seems reasonable to suggest that the serpentine outcrops may provide one of the more extreme growth conditions for this species. However, in these environments, L. californica achieves dominance and is often restricted to the serpentine side of the serpentine and nonserpentine boundary. Thus, L. californica fits Kruckeberg's third category of plant distributions on serpentine soils, species that are widespread on serpentine and nonserpentine soils but 
show regional prominence on serpentine (Kruckeberg, 1984).

The existence of flavonoid races in L. californica was first noted in a study of individual plants along several transects established on a serpentine outcrop located in the Jasper Ridge Biological Preserve of Stanford University. Two principal pigment profiles were noted, race $\mathrm{A}$, characterized by the presence of flavonol diglycoside sulfates and the flavanone eriodictyol 7-O-glucoside, and race $\mathrm{C}$, which lacked both of those compound types. Moreover, race A plants were found only in the lower third of the transect, whereas race $\mathrm{C}$ plants occurred in the upper two-thirds of the transect. Both races exhibited a complex array of anthochlors (aurones and chalcone glycosides) as reported in the original description of the flavonoid chemistry of the genus (Bohm, Saleh, and Ornduff, 1974). (A minor variant of race $C$, referred to in earlier papers as race $\mathrm{B}$, contains luteolin 7-O-glucoside). The existence of chemical races in itself was not a novel observation (see Bohm, 1987, for a discussion of flavonoid races), but the maintenance of a more or less clearcut line of demarcation between the two races over a period of years, six in the original study, did attract our attention. Subsequent to those studies it has been observed that the geographical pattern within the study site has remained essentially unchanged for at least $15 \mathrm{yr}$ (Desrochers and Bohm, 1993; Rajakaruna and Bohm, unpublished data). It is of interest to note that the finding of differentiated populations within a serpentine site represents a new phenomenon-other reports in the literature being concerned with differences between species pairs, one of which grows on serpentine and the related one on nonserpentine soil (Kruckeberg, 1951, 1954, 1967, 1969, 1992, personal communication; Proctor and Woodell, 1975; Brooks, 1987; Mayer and Soltis, 1994).

The finding of flavonoid variation within the Jasper Ridge population prompted us to investigate other features of the system. Results of those investigations included the existence of clear-cut morphological and electrophoretic differences (Desrochers and Bohm, 1995): race A plants are characterized by the presence of a linear pappus, the B allele coding for NADHDH and faster moving allozymes coding for 6PGD-1, whereas race $\mathrm{C}$ plants are characterized by a lanceolate pappus, the A allele coding for NADHDH and slower alleles coding for 6PGD-1. Preliminary crossing studies between the two races were inconclusive owing to the small number of crosses that were performed. Current crossing studies indicate that the two plant races have only a limited capacity to cross (data not included; Rajakaruna and Bohm, unpublished data). The absence or very low level of gene exchange and the observed differences in flowering time in the field of 7-10 d (Desrochers and Bohm, 1995; Rajakaruna and Bohm, unpublished data) suggest the existence of a strong prezygotic breeding barrier.

Greenhouse experiments indicated that the flavonoid profiles seen within populations of $L$. californica are genetically controlled. Thus, the flavonoid chemistry of an offspring, with very few exceptions, matched that of its maternal parent (we have no way of determining pollen source at this time) (Bohm et al., 1989). The offspring reared from field-collected seed were germinated and maintained in potting soil without apparent effect upon

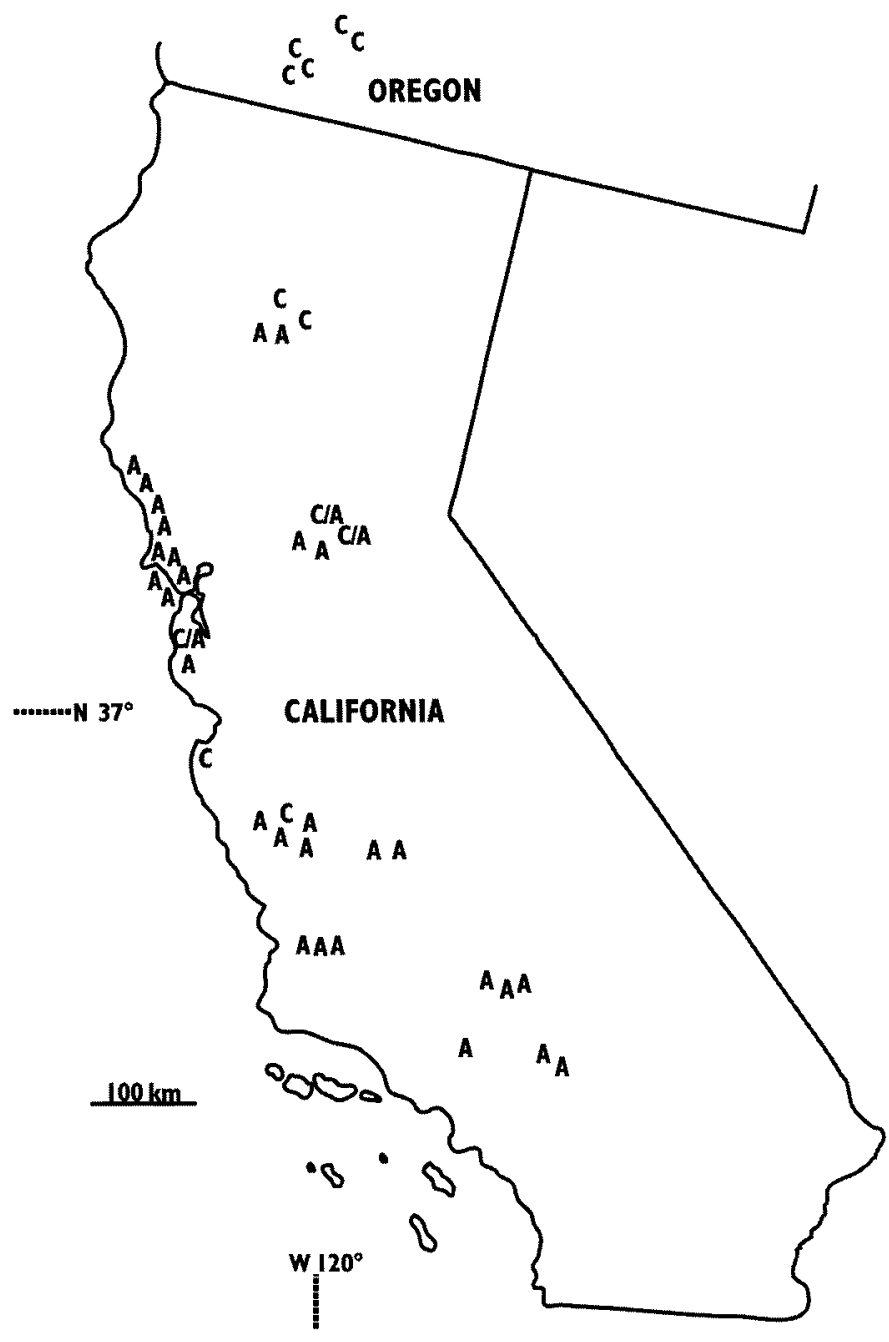

Fig. 1. Distribution of race A and race C populations sampled between 1996 and 1998.

the flavonoid profile. It appears, therefore, that differences in the pigment profiles of the two races are not the immediate result of substrate differences.

An extension of the flavonoid survey to include representatives from the entire range of $L$. californica established that the two races exhibit a reasonably clear-cut pattern of occurrence. Race C plants were found to occur predominantly from southern Oregon through northern California to north-central California, whereas race A plants were found predominantly in the southern parts of California, Arizona, and in Baja California (Desrochers, 1992; Desrochers and Bohm, 1993). A few mixed populations, including the population at Jasper Ridge, were observed in the central part of California. This distribution is represented in Fig. 1.

Owing to the unusual partitioning of variation within the Jasper Ridge site, particularly with regard to its constancy over time, it was decided to investigate the possible effects of soil chemistry on the expression of the phenotypes observed. The fundamental issue addressed in the present study, then, involves an examination of factors that might be involved in maintaining race A plants in the lower part of the transect and race $\mathrm{C}$ plants 
in the upper part. In the following, we describe analyses of soil samples collected along several transects at the Jasper Ridge site for elemental composition, electrical conductivity (ionic strength), $\mathrm{pH}$, moisture content, and clay content. The capacity of individual plants to accumulate certain ions was also investigated. The study was expanded to include analyses of soils and individual plants from populations collected from known sites in Oregon and from sites representing the range of the species in California. With those data in hand, several experiments were run in order to assess the effects of the different soils involved on germination and growth of plants representing the two races.

\section{MATERIALS AND METHODS}

Collection sites-Individual plants and soil samples were collected along six transects established in the Jasper Ridge Biological Preserve of Stanford University. The preserve is located west of Palo Alto, California, San Mateo County, in the Santa Cruz Mountains. The collection site lies at an approximate elevation of $180 \mathrm{~m}$. Approximate coordinates of the Preserve are $37^{\circ} 25^{\prime} \mathrm{N}$ and $122^{\circ} 2.5^{\prime} \mathrm{W}$. The area of interest is an extensive serpentine outcrop that runs in a west-northwesterly to eastsoutheasterly direction. A detailed classification of rock and soil associations on this outcrop has been provided by Armstrong and Huenneke (1992).

In April, 1996 plant and soil samples were collected along five transects on the serpentine outcrop at the Jasper Ridge site. The arrangement of these transects is shown diagrammatically in Fig. 2. (Transects 2, 3, and 5 correspond to transects I, II, and IV in Desrochers and Bohm, 1993.) The length of these transects range from 44 to $65 \mathrm{~m}$. The north and south ends of the $100 \mathrm{~m}$ transect described by Armstrong and Huenneke (1992) is, respectively, $150 \mathrm{~m}$ and $95 \mathrm{~m}$ west of our transect 3 (Nona Chiariello, personal communication, Jasper Ridge Biological Preserve, Stanford University). One hundred twenty-three plant and soil samples were collected at 2-m intervals along all of the transects. In April, 1997 plants were collected along a new transect (transect 6), a $50-\mathrm{m}$ transect running parallel to the oak-grassland boundary between the bottom ends of transects 2 and 5. An $\sim 7 \%$ drop exists between the fire road and the oak-grassland boundary terminus of transect 3 .

Twenty-two additional sites, listed in Table 1, were sampled in this study, five from southern Oregon and 17 representing the range of the species in California. Site 11 is a population in the Jasper Ridge Preserve that lies at some distance $(\sim 1 \mathrm{~km})$ from the study transects. Figure 3 is a map of the area covered by these collections.

Field collections-Four to 10 plants were collected at each $2-\mathrm{m}$ interval point along all transects. The plants are slightly pubescent, not glandular or sticky. Plants were cleaned of adhering soil/dust by gentle shaking in the field. Plants were placed separately in paper bags for later determination of elemental composition of plant tissue. Several flower heads from each individual plant were collected to obtain achenes for germination studies (placed in seed envelopes) as well as for analysis of flavonoid profiles (placed in small glass vials).

Approximately $300 \mathrm{~g}$ of soil from the rooting zone of each collection site were dug and placed in plastic bags. All soil samples were collected at $0-10 \mathrm{~cm}$ depth using a plastic hand trowel (thus avoiding possible contamination of soil samples by $\mathrm{Cr}$ or $\mathrm{Ni}$ from a stainless steel trowel). At several points along each transect samples were collected and placed in air-tight soil cans for determination of water content. For populations other than Jasper Ridge, three samples were selected at "random." Again, 4-10 plants and $\sim 300 \mathrm{~g}$ of soil were collected.

Analytical procedures-Plants-Whole plants were cleaned of adhering soil/dust by use of a gentle pressurized air stream in a fumehood and dried for $24 \mathrm{~h}$ at $80^{\circ} \mathrm{C}$ in a forced draft oven. Each sample was

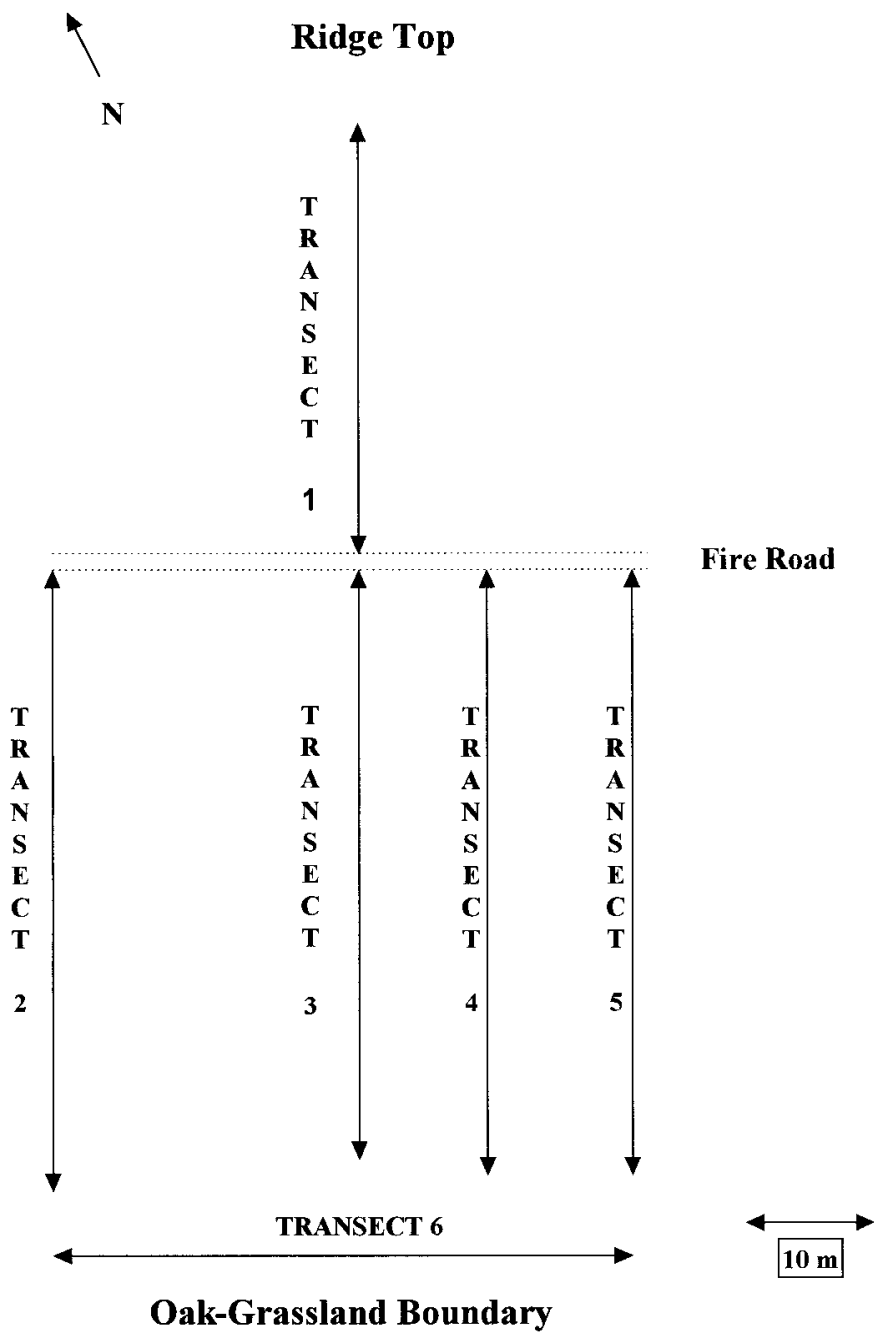

Fig. 2. Arrangement of transects on the serpentine outcrop at Jasper Ridge Biological Preserve.

then thoroughly ground using a Model CG 150 Sunbeam Café Mill. Trials were conducted using pine needles to see whether the stainless steel blades of the mill contributed traces of $\mathrm{Cr}$ to the ground plant material. There was an $\sim 1 \%$ increase in this metal using this grinding method. All analytical analyses for $\mathrm{Cr}$ were corrected by this value. Ground plant material was then extracted using $1 \mathrm{~mol} / \mathrm{L} \mathrm{HNO}_{3}$ and 2 $\mathrm{mol} / \mathrm{L} \mathrm{HCl}$ (all procedures followed are described in the UBC Soil Science Laboratory Manual, 1981). Digested samples were then analyzed for aluminum, calcium, chromium, copper, iron, magnesium, manganese, nickel, potassium, sodium, and zinc.

One-dimensional thin layer chromatography of flower extracts was run as described earlier (Derochers and Bohm, 1993).

Analytical procedures-Soils-All soil samples (except those used for moisture content analysis) were placed on plastic trays and air-dried at room temperature for $\sim 1 \mathrm{wk}$. Each sample was then sieved (fumehood) with a homemade wood-frame fitted with 2-mm nylon mesh. Gravel was removed from the remaining aggregate of soils and then crushed using a wooden rolling pin. The resulting material was passed through the sieve, and the entire process was repeated until all soil aggregates had been crushed. Crushed soil samples were stored in plastic bags.

For the determination of moisture content (relative water content) soil samples were weighed immediately upon opening the sealed metal cans 
TABLE 1. Locality information for samples of Lasthenia californica from Oregon and California.

\begin{tabular}{cl}
\hline \hline $\begin{array}{c}\text { Population } \\
\text { no. }\end{array}$ & \multicolumn{1}{c}{ Locality information } \\
\hline 1 & Along Highway 234, 2.9 km west of intersection with Table Rock Rd., near Gold Hill, Jackson Co., OR. \\
2 & Roadside, Kirtland Rd., $0.5 \mathrm{~km}$ from intersection with Table Rock Rd., near water treatment plant, Jackson Co., OR. \\
3 & Across road from population No. 2, Jackson Co., OR. \\
4 & Summit of Table Rock, near southern end of mesa, Jackson Co., OR (andesite). \\
5 & Summit of Table Rock, near northern end of mesa, Jackson Co., OR (andesite). \\
6 & Pasture along Rt. 36, 1.7 km from intersection with Highway 99, near Red Bluff, Tehama Co., CA. \\
7 & Roadside along Paskenta/Covelo Rd., 5.1 km W of Paskenta Bridge, Paskenta, Tehama Co., CA. \\
8 & Hillside $4 \mathrm{~km} \mathrm{E} \mathrm{of} \mathrm{Paskenta} \mathrm{Bridge,} \mathrm{Paskenta/Covelo} \mathrm{Rd.,} \mathrm{Paskenta,} \mathrm{Tehama} \mathrm{Co.,} \mathrm{CA} \mathrm{(serpentine).}$ \\
9 & Pasture on Highway 104, 13.9 km E of Clay, Sacramento Co, CA. \\
10 & Roadside at railroad crossing and Highway 104, near Clay, Sacramento Co., CA. \\
11 & Rattle Snake Rock, north-facing slope, Jasper Ridge Biological Preserve, San Mateo Co., CA (serpentine). \\
12 & Pasture, 4 km E of population 9 on Rt. 104, Sacramento Co., CA. \\
13 & Pasture, 2.9 km E of population 9 on Rt. 104, Sacramento Co., CA. \\
14 & Pasture along Rt. 198, 4 km NW of County line of Monterey and Fresno Counties, Priest Valley, Monterey Co., \\
15 & CA. \\
16 & Pasture at intersection of Rt. 198 and Priest Valley Rd., Monterey Co., CA. \\
17 & Pasture at entrance to Palmer Ranch, off Priest Valley Rd., Monterey Co., CA. \\
18 & Along road to Palmer Ranch, off Priest Valley Rd., Monterey Co., CA. \\
19 & NE corner of Coalinga Springs Rd. and Rt. 198 Fresno Co., CA. \\
20 & Pasture, 1 km E of Coalinga Springs Rd. on Rt. 198, Fresno Co., CA. \\
21 & Hillside north of 16-Mile Road on trail to stream, ca. 4 km from Arroyo Seco campsites, Los Padres National For- \\
22 & est, Monterey Co., CA. \\
& Along Tehachapi Willow Springs Rd., 3.3 km S of intersection Highline and Tehachapi Willow Springs Rd., Kern \\
& Co., CA. \\
\end{tabular}

in which the samples had been placed in the field to determine wet mass. The samples were then dried at $105^{\circ} \mathrm{C}$ for $16 \mathrm{~h}$ and reweighed.

Soil color was determined by comparing appropriate samples using the Munsell Soil Color Charts (1992). Six soil samples from each race of $L$. californica were subjected to the color test under both dry and wet conditions. Soil texture was determined by particle size analysis using the Hydrometer Method and the computer program METLAB (UBC Soil Science Laboratory Manual, 1981).

Soil $\mathrm{pH}$ was determined using both water and calcium chloride solution. Ten grams of soil from each sample were mixed with $20 \mathrm{~mL}$ water or $20 \mathrm{~mL} 0.01 \mathrm{~mol} / \mathrm{L}$ calcium chloride solution. The suspensions were stirred several times over a period of $30 \mathrm{~min}$ and allowed to stand for $1 \mathrm{~h}$. After the particulate material had settled $\mathrm{pH}$ was measured using an Orion (Boston, Massachusetts) Model 420A pH meter (Black et al., 1965; UBC Soil Science Laboratory Manual, 1981).

Cation exchange capacity (CEC) and exchangeable cations $\left(\mathrm{Ca}^{2+}, \mathrm{K}^{+}\right.$, $\mathrm{Mg}^{2+}, \mathrm{Na}^{+}$) were determined by the ammonium acetate method at $\mathrm{pH}$ 7.0 using $1 \mathrm{~mol} / \mathrm{L}$ ammonium acetate and $1 \mathrm{~mol} / \mathrm{L}$ potassium chloride according to a procedure described by Black et al. (1965). Exchangeable aluminum was determined by extraction of soil samples with $1 \mathrm{~mol} / \mathrm{L}$ potassium chloride following Page, Miller, and Keeney (1982). Total nitrogen was determined by the Kjeldhal method. Concentrations of exchangeable cations were determined by atomic absorption spectroscopy using a Perkin Elmer Corp. (Norwalk, Connecticut) Model 306 instrument. Total CEC and total nitrogen were also determined using a Lachat Instruments (Milwaukee, Wisconsin) Quick Chem automated ion analyzer (Model 2300-000). Micronutrients, cadmium, chromium, cobalt, copper, iron, manganese, and zinc were extracted with dimethylenetriaminepentacetic acid (DTPA) using $0.005 \mathrm{~mol} / \mathrm{L}$ DTPA, 0.01 $\mathrm{mol} / \mathrm{L}$ calcium chloride, and $0.1 \mathrm{~mol} / \mathrm{L}$ triethylamine (TEA) adjusted to pH 7.3 with dilute hydrochloric acid (Lindsay and Norvell, 1978). Concentrations of extracted elements were determined by inductively coupled plasmaspectroscopy (ICP) using a Thermo Jarrell Ash (Waltham, Massachusetts) ICP 61 instrument.

Electrical conductivity (EC) of soil solutions was determined using the analytical method described by Kalra and Maynard (1991) except that samples were extracted for $30 \mathrm{~min}$ rather than $4 \mathrm{~h}$. Conductivity measurements were made using a Type CDC 104 conductivity cell using a Radiometer Type CDM 2 conductivity meter (Copenhagen, Denmark). Ionic strength (I) was calculated using the equation described by Alva, Sumner, and Miller (1991).

Measurement of achene size-Mean length and width of achenes of race $\mathrm{A}$ and race $\mathrm{C}$ plants collected from the Jasper Ridge site were determined using standard measurement techniques. Achene masses were determined using an analytical balance.

Germination and growth studies-Preliminary studies had shown that achenes require at least a 3-mo period of after-ripening (dormancy) for optimal germination.

Approximately $3 \mathrm{~kg}$ of soil was collected from two spots on transect 3 , one near the top of transect and one near the bottom. These represented sites where race $\mathrm{C}$ and race A plants, respectively, had been identified. Soils were air-dried for $1 \mathrm{wk}$ and then crushed and sieved through a stainless steel (contamination by trace metals was not considered significant for the growth experiments) standard mesh number 4 sieve to obtain the $<4.75 \mathrm{~mm}$ fraction. Two hundred grams were then placed separately in plastic dishes $(12.5 \times 12.5 \times 4.5 \mathrm{~cm})$ and thoroughly soaked with water to bring the soil to saturation $(\sim 200 \mathrm{~mL}$ required). Dishes were placed in a cold room $\left(5^{\circ} \mathrm{C}\right)$ in the dark for 1 wk to stimulate germination of Lasthenia or other seed from the natural seed bank. Dishes were then moved to the greenhouse and observed for $1 \mathrm{wk}$. All germinants, mostly grasses, were removed. (No Lasthenia seedlings were observed.)

Once the soils were rid of possible germinants from the natural seed bank, soils were thoroughly watered once again. Thirty achenes from race $\mathrm{A}$ and race $\mathrm{C}$ plants were sown separately on four dishes each containing the three soil types, race A type soil, race $\mathrm{C}$ type soil, and potting soil (Terra Lite Soil Mix, W.R. Grace and Co. of Canada Ltd., Ajax, Ontario, Canada). Dishes were returned to the cold room and arranged randomly and left in the dark for $1 \mathrm{wk}$. After the cold treatment, the dishes were moved to the greenhouse and monitored from day 8 onwards. Germinants were scored on the basis of emergence of radicle. From days 9 to 36 plant survival was scored daily on the basis 


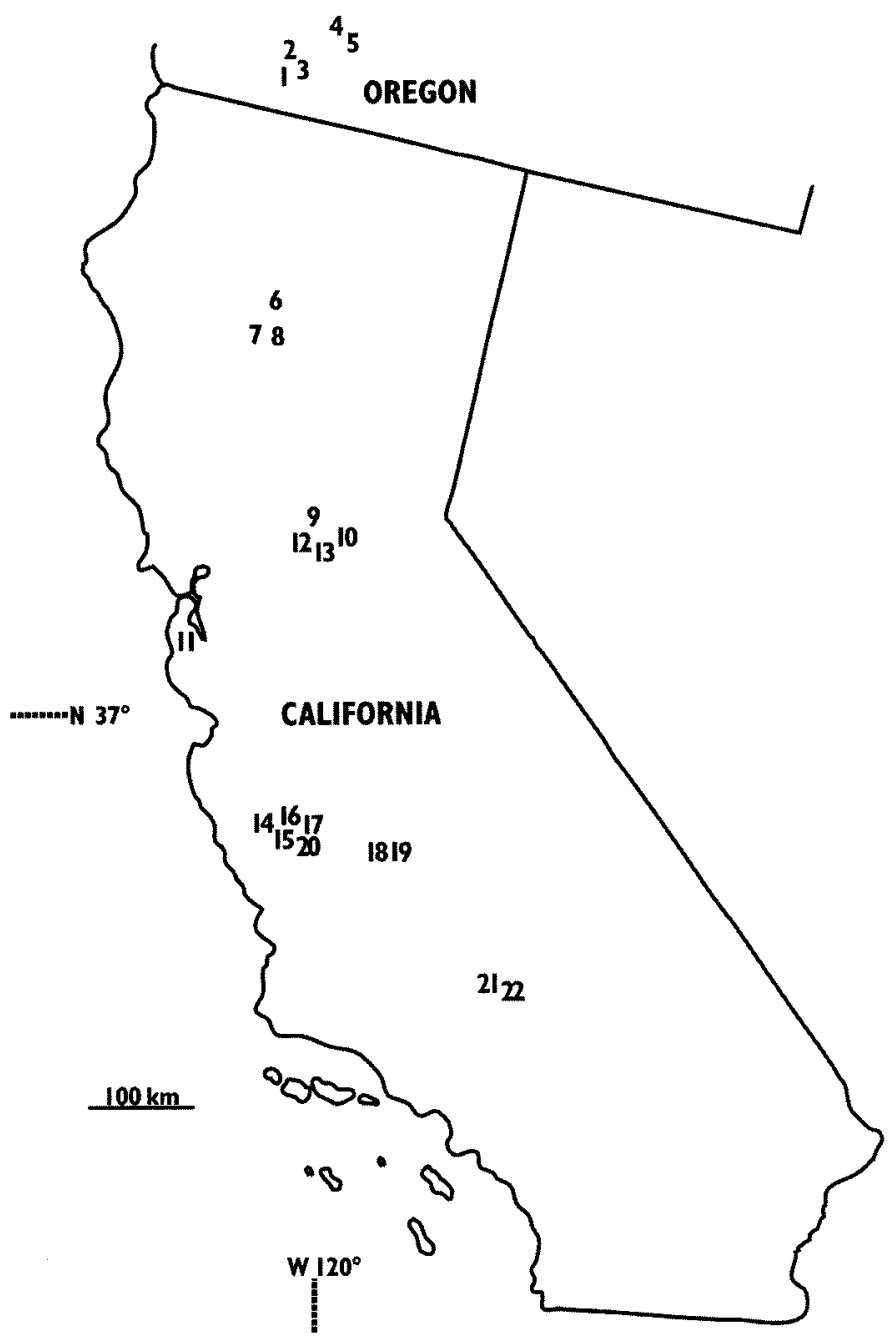

Fig. 3. Distribution of the populations sampled for soil and plant tissue analyses.

of percentage of standing plants with healthy foliage. The final count was done $60 \mathrm{~d}$ after sowing. Plants that were either dead or wilted were not taken into the daily count. However, if a plant revived by the following day it was included in the count of standing plants.

After each count each dish was given $100 \mathrm{~mL}$ tap water. Watering was done daily to day 11 , then on days $15,16,20,24,28,29$, and 35 . This watering regime was designed to provide periods of "minidrought" characteristic of the natural conditions under which these plants are often found. The temperature ranged between $70^{\circ}$ and $90^{\circ} \mathrm{F}$ during the growth period, daylength was $\sim 14 \mathrm{~h}$, and humidity was maintained at $70-80 \%$.

Effects of soil treatments on plant growth involved measuring plant height, number of leaves per plant, and percentage of plants that developed inflorescences during the experimental period. Plant height and number of leaves were measured on 3-wk-old plants. Height was measured from base of stem to the tip of the tallest leaf. The date of opening of the first inflorescence was recorded as well as the number of plants with inflorescences on day 45 after germination.

Germination and growth experiments using soil solutions-Fiftygram samples of the two natural soil types were each mixed with 50 $\mathrm{mL}$ of distilled water, shaken for $30 \mathrm{~min}$, and then centrifuged at 10 $000 \mathrm{rpm}$ for $5 \mathrm{~min}$ using a Beckman J2-21M/E Centrifuge (Palo Alto, California). The supernatant from each was filtered through Whatman
Number 42 filter paper. Fifteen achenes of each race were sown on Whatman Number 42 filter paper placed in plastic petri dishes $(100 \times$ $15 \mathrm{~mm}$ ) and soaked with the appropriate solution, type A soil extract, type $\mathrm{C}$ soil extract, and distilled water. Each treatment was replicated four times. After standing in the dark at $5^{\circ} \mathrm{C}$ for $1 \mathrm{wk}$, the plates were moved to a growth chamber and maintained at $25^{\circ} \mathrm{C}$ during the $12-\mathrm{h}$ day and $20^{\circ} \mathrm{C}$ at night. A few drops of the appropriate solution were added to each dish daily. On day 8 achenes showing emergence of the radicle were scored.

Seed bank study-As noted, no Lasthenia californica plants were observed in the germination experiment described above. Seed bank studies were extended to include larger samples of soil from the upper and lower termini of transects 2, 3, and 5. Samples were collected from the surface to $\sim 5 \mathrm{~cm}$ depth and placed in large plastic trays $(50 \times 20$ $\times 5 \mathrm{~cm}$ ). Samples from each terminus were placed in two trays each. Trays were watered thoroughly and exposed to cold $\left(5^{\circ} \mathrm{C}\right)$ and dark for 1 wk. Trays were then moved to the greenhouse, arranged randomly, and watered as needed. Observations were made on the composition of germinants for a period of $6 \mathrm{mo}$.

Observations on achene dispersal-Observations were made in the field on possible distance of achene dispersal. Plants were either tapped gently or exposed to a gentle current of air to see how far achenes dislodged by these treatments disperse.

Statistical analyses-Plant tissue and soil analyses-The soil and plant data sets were tested for normality and homogeneity of variance by using the Shapiro Wilks and the Levene tests, respectively. Once the assumptions of both normal distribution and equal variances were found to be applicable to the data sets, one-way analysis of variance (ANOVA) was used to determine whether means of soil and plant tissue variables differed for race $\mathrm{A}$ and race $\mathrm{C}$ plants. Regression analyses were used to examine functional relationships between soil concentrations of various elements and those element concentrations in plants. Discriminant function analyses (DFA) and principal components analysis (PCA) were conducted to determine whether soil and plant tissue characteristics were reliable as indicators of the race of individual plants.

Germination and growth studies-The data sets were tested for ner mality and homogeneity of variance as above. One-way analysis of variance was used to determine whether means of percentage germination and various growth measures of the two races differed among the three soil treatments. Paired-sample $t$ tests were used when means of various growth measures had to be compared in a pairwise manner.

All tests were conducted using statistical packages SPSS (Norusis, 1993) and SYSTAT:Statistics Version 5.2 (Wilkinson, Hill, and Vang, 1992) running on IBM-compatible computers at the Department of Botany, UBC.

\section{RESULTS}

Flavonoid profiles - Examination of the flavonoid profiles of individuals collected along all of the Jasper Ridge transects confirmed the existence of two pigment races with the race $A$ plants occupying the lower and race $C$ plants the upper reaches of the transects (Fig. 4). The lines of demarcation of the races agreed with those reported in earlier studies (Bohm et al., 1989; Desrochers and Bohm, 1993). Thus, the pattern of distribution of these two pigment types at the Jasper Ridge site have remained essentially unchanged for a period of at least 15 yr. Examination of individual plants from the other sites visited in this study also confirmed the findings of Desrochers and Bohm (1993). 


\section{TRANSECT 1}

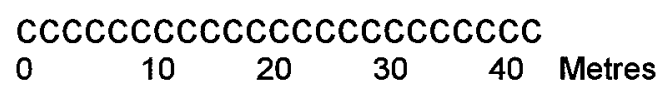

\section{TRANSECT 2}

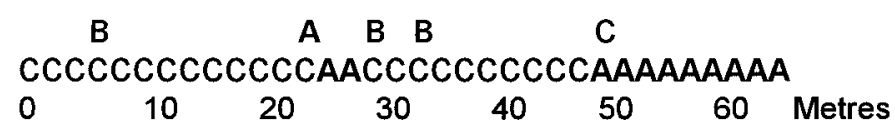

TRANSECT 3

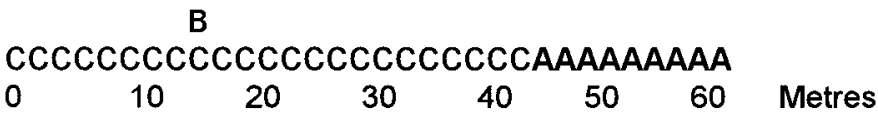

\section{TRANSECT 4}

$\begin{array}{llllllll}\mathrm{CC} & & & \mathrm{CC} & & & \text { AA } & \\ 0 & 10 & 20 & 30 & 40 & 50 & 60 & \text { Metres }\end{array}$

\section{TRANSECT 5}

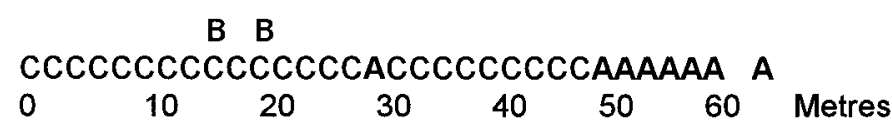

\section{TRANSECT 6}

\section{AAAAAAAAAAAAAAAAAAAAAAAAAA}

\section{$\begin{array}{lllllll}0 & 10 & 20 & 30 & 40 & 50 & \text { Metres }\end{array}$}

Fig. 4. Flavonoid pattern of plants collected along six transects at Jasper Ridge Biological Preserve. For transects 1-5 distance 0 is at Fire Road. Transect 6 is along oak-grassland boundary.

Achene size-Measurements of the length, width, and mass of achenes of the two races of $L$. californica collected at the Jasper Ridge site showed significant differences. Although longer, achenes of race $\mathrm{C}$ were shown to be significantly narrower and to weigh less than those of race A plants. These data are presented in Table 2.

Soil color-The colors of the soils collected from Jasper Ridge are noticeably different; soil from the upper collection sites, which support race $\mathrm{C}$ plants, are dark brown, whereas those from the lower sites, which support race A plants, are very dark greyish brown.

Soil analyses-The first set of analytical values for the soil analyses allows a comparison between soils from sites supporting race $\mathrm{C}$ plants (93 individuals) and soils supporting race A plants (30 individuals). This data set represents all individuals sampled from all transects. Percentage clay content, relative water content (RWC), cation exchange capacity (CEC), $\mathrm{pH}$, electrical conductivity (ionic strength), and exchangeable magnesium and sodium were significantly higher (all $P<0.0001$ ) in soils harboring race A plants (type A soils) than in soils harboring race $\mathrm{C}$ plants (type $\mathrm{C}$ soil). Conversely, type $\mathrm{C}$ soils had significantly higher mean values for exchangeable calcium and potassium, extractable nickle, and calcium:magnesium ratios. Table 3 presents relevant data for these analyses.

Plant elemental analyses-Elemental composition of individual plants along all of the transects resulted in the data set presented in Table 4. The individual plants analyzed correspond to the sites for which soil data were obtained as described immediately above. Means for total aluminum, magnesium, sodium, and zinc were significantly higher in plant tissue of race A plants $(P<0.01)$, whereas means for calcium and potassium were significantly higher in plant tissue of race $\mathrm{C}$ plants $(P<0.02)$. The calcium:magnesium ratio was also significantly larger in race $\mathrm{C}$ plants than in race A plants $(P<0.0001)$. Chromium, copper, iron, and manganese showed no obvious patterns in their distribution.

Soil and plant tissue analyses along transect 3-Table 5 presents results of analysis of soil samples taken at 2$\mathrm{m}$ intervals along transect 3 . The plant at metre 16 was the only representative of the subset of race $\mathrm{C}$ known as race $\mathrm{B}$. Note the transition from race $\mathrm{C}$ to race $\mathrm{A}$ plants at the 46-m position. This transition between the two plant types has remained constant for the duration of studies at the Jasper Ridge site (15 yr). Percentage moisture was determined at 12 points along the transect and percentage clay content at six points. All other measures were determined at all points along the transect. Table 6 presents the results of elemental analyses of the plants collected along transect 3 . The points of collection correspond to those for the soil data presented in Table 5.

Values for soil characteristics along transect 3 are plot-

TABle 2. Mean \pm 1 SE length, width, and mass of achenes of $L$. californica race A and race C plants collected at Jasper Ridge. Significance based on a one-way analysis of variance.

\begin{tabular}{lcccc}
\hline \hline \multicolumn{1}{c}{ Achene character } & $N$ & Race A & Race C & $F$ \\
\hline Length $(\mathrm{mm})$ & 127 & $1.84 \pm 0.012$ & $2.16 \pm 0.018$ & $P<0.0001$ \\
Width $(\mathrm{mm})$ & 50 & $0.411 \pm 0.004$ & $0.312 \pm 0.004$ & $P<0.0001$ \\
Mass of 20 achenes $(\mathrm{mg})$ & 25 & $1.78 \pm 0.03$ & $1.34 \pm 0.03$ & $P<0.0001$ \\
\hline
\end{tabular}


TABLE 3. Soil characteristics for Jasper Ridge. Concentration of elements given in ppm ( $\mu \mathrm{g} / \mathrm{g}$ soil).



${ }^{\mathrm{a}} \mathrm{RWC}=$ relative water content, $\mathrm{CEC}=$ cation exchange capacity, $\mathrm{EC}=$ electrical conductivity, $I=$ ionic strength.

ted as a function of distance along that transect in Fig. $5 \mathrm{a}-\mathrm{i}$. These figures show values for $\mathrm{pH}$, cation exchange capacity (CEC), electrical conductivity, ionic strength, magnesium, sodium, calcium, the calcium:magnesium ratio, and potassium plotted against distance along the transect. Figure $5 \mathrm{a}-\mathrm{f}$ shows that various measures gradually increase as a function of distance along the transect, and that there is a significant increase beyond the transition point (race $\mathrm{C}$ to race $\mathrm{A}$ ) with the highest values often recorded for the bottommost samples. Conversely, Fig. $5 \mathrm{~g}-\mathrm{i}$ demonstrates that other measures show a significant decrease beyond the transition point with the lowest val- ues often recorded for the bottommost samples. A corresponding set of figures, Fig. $6 \mathrm{a}-\mathrm{h}$, shows the relationships between elemental composition of plant tissue and distance along transect 3 . Both plant races showed significant correlations between soil and plant tissue concentrations of calcium and sodium as well as with the calcium:magnesium ratios. Correlations are higher for race A plants than they are for race $\mathrm{C}$ plants. Some differences were noted between the two races: magnesium is significantly correlated for race A plants but not for race $\mathrm{C}$ plants, whereas potassium is significantly correlated for race $\mathrm{C}$ plants but not for race $\mathrm{A}$ plants. For other 
TABLE 4. Elemental analyses of plant tissue comparing race A and race C plants. Concentrations of elements given in ppm ( $\mu \mathrm{g} / \mathrm{g}$ plant tissue).

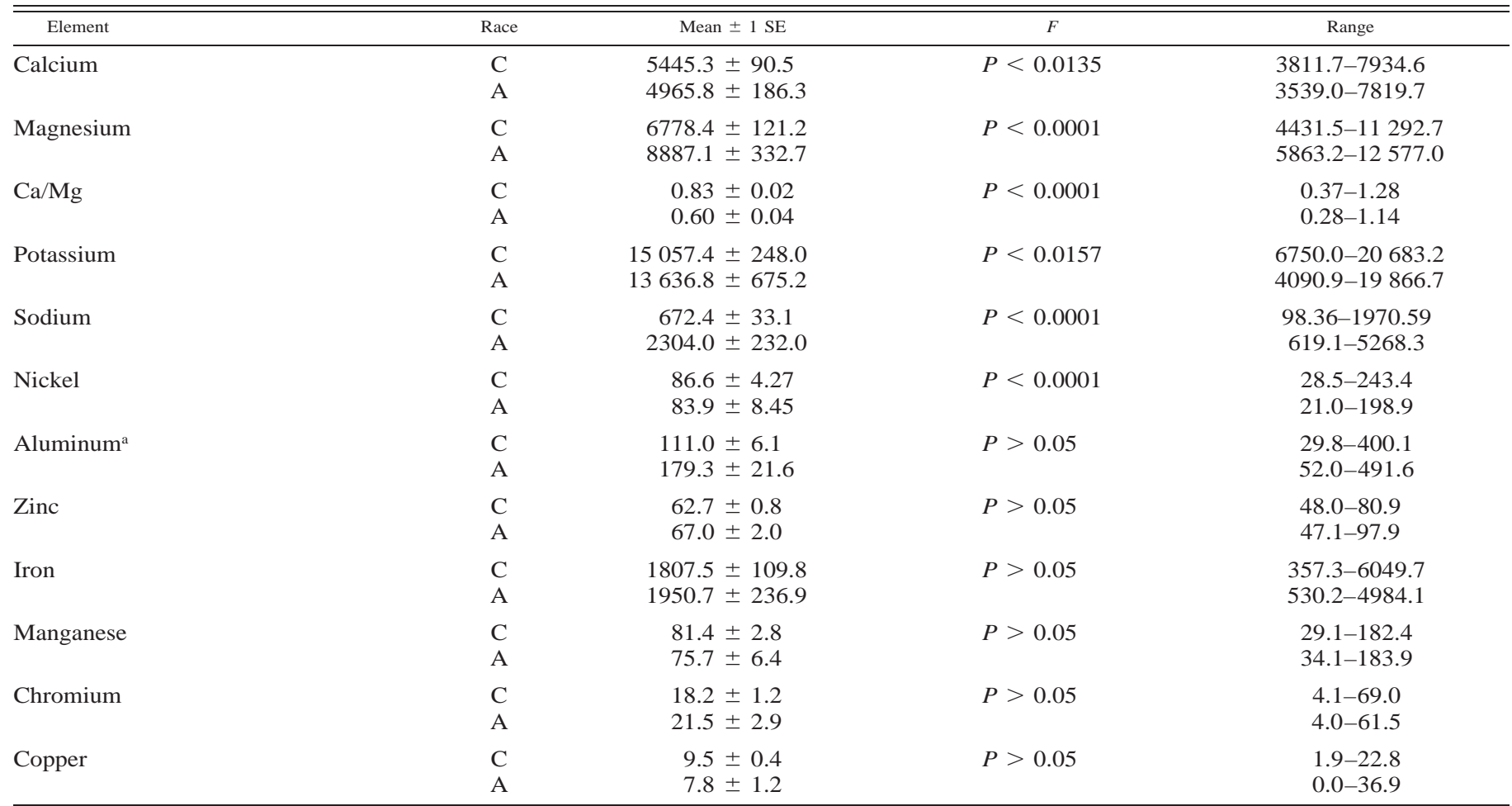

${ }^{a}$ Four samples tested.

metals the correlations were not significant for either race. Results from the correlation analyses are presented in Table 7. The linear relationships between soil and plant tissue concentrations for magnesium and sodium are shown in Fig. $7 \mathrm{a}$ and b.

Soil and plant tissue analysis of other populationsSoil samples from 22 sites representing the range of $L$. californica in southern Oregon and California were analyzed for the same suite of features as described for the Jasper Ridge soils (Table 3). Data arising from these analyses are presented in Table 8 . Soil $\mathrm{pH}$ and exchangeable magnesium were shown to be significantly greater $(P<$ 0.02 ) in soils harboring race A plants compared to soils harboring race $\mathrm{C}$ plants. Values for percentage clay content, CEC, electrical conductivity (EC), ionic strength, and exchangeable sodium were also greater for soils of race A plants, although the differences were not statistically significant $(P>0.05)$. Several differences were observed between the patterns from Jasper Ridge and those from the other analyses. For example, exchangeable potassium was significantly higher in soils of race A plants from the other sites than was seen for soils of race A plants at Jasper Ridge. Similarly, exchangeable calcium and nickel were higher for race A plants from the other sites, although the values were not statistically significant $(P>0.05)$. The difference between the means of EC measurements was not significant $(P>0.05)$. It is of interest to note that the highest electrical conductivity value so far observed for the soils of the species was recorded for a race A population recently collected from Soda Lake, San Luis Obispo County, California ( 330 $\mathrm{km}$ southeast of Jasper Ridge). Electrical conductivities above $4 \mathrm{mS} / \mathrm{cm}$ are highly toxic to most plants (Brady, 1990), and the value of $7.49 \mathrm{mS} / \mathrm{cm}$ recorded for the soils of this population clearly indicates the high salt-tolerant capacity of this race.

Results of analysis of plant tissues from the other collection sites are presented in Table 9. The results are in general agreement with those from the Jasper Ridge site analyses, although the majority of differences were not statistically significant at $P<0.05$. However, significant differences were observed in the higher concentrations of aluminum $(P<0.0001)$, iron $(P<0.011)$, and manganese $(P<0.0001)$ in soils harboring race $C$ plants. Relationships between soil and plant tissue concentrations of elements were calculated for collections from the other sites, as was done for the Jasper Ridge site (Table 7). Table 10 presents the results of the correlation analyses. Significant correlations were observed for race A plant and soil concentrations of calcium, magnesium, sodium, nickel, and zinc. Significant correlations between race C plant and soil concentrations of chromium and nickel were observed.

Discriminant function analysis-Discriminant function analysis was performed in order to determine how well soil and plant tissue chemistry could be used to predict races of $L$. californica. Analysis of soil samples indicated significantly different $(P<0.0001)$ group means (centroids) for soils of both races, informing us that soil chemistry is highly reliable in predicting race. Soil $\mathrm{pH}$, magnesium, sodium, and the calcium:magnesium ratio, in that order, were the most discriminating variables. The 
TABLE 6. Elemental composition of plants taken at 2-m intervals along transect 3. Concentration given in $\mu \mathrm{g} / \mathrm{g}$ (ppm) dry mass of plant material.

\begin{tabular}{|c|c|c|c|c|c|c|c|c|c|c|c|c|c|}
\hline $\begin{array}{l}\text { Coll. } \\
\text { no. }^{a}\end{array}$ & $\begin{array}{l}\text { Plant } \\
\text { race }\end{array}$ & $\mathrm{Ca}$ & $\mathrm{Mg}$ & $\mathrm{Ca} / \mathrm{Mg}$ & $\mathrm{Na}$ & $\mathrm{K}$ & $\mathrm{Al}$ & $\mathrm{Fe}$ & $\mathrm{Cu}$ & $\mathrm{Zn}$ & $\mathrm{Cr}$ & $\mathrm{Mn}$ & $\mathrm{Ni}$ \\
\hline 2 & $\mathrm{C}$ & 7934 & 7707 & 1.03 & 579 & 14789 & 183 & 3729 & 8.53 & 65.0 & 37.1 & 133.2 & 152.2 \\
\hline 4 & C & 6504 & 8477 & 0.77 & 815 & 14556 & 164 & 3172 & 10.8 & 53.4 & 33.6 & 111.0 & 149.5 \\
\hline 8 & C & 5182 & 9404 & 0.55 & 447 & 13934 & 215 & 4063 & 7.68 & 53.0 & 39.8 & 133.1 & 162.2 \\
\hline 10 & C & 5029 & 8320 & 0.60 & 800 & 15300 & 191 & 3272 & 19.5 & 61.0 & 34.7 & 114.9 & 146.3 \\
\hline 12 & $\mathrm{C}$ & 6057 & 7065 & 0.86 & 846 & 16154 & 84 & 1643 & 1.87 & 55.4 & 13.7 & 74.8 & 73.7 \\
\hline 18 & $\mathrm{C}$ & 4756 & 6952 & 0.68 & 621 & 20683 & 131 & 2769 & 8.03 & 62.3 & 25.2 & 110.9 & 110.5 \\
\hline 20 & C & 4154 & 7476 & 0.56 & 594 & 14660 & 116 & 1871 & 7.34 & 57.1 & 19.7 & 71.1 & 83.7 \\
\hline 22 & C & 4673 & 7662 & 0.61 & 1470 & 10783 & 102 & 1597 & 7.97 & 50.9 & 15.0 & 69.3 & 77.6 \\
\hline 24 & C & 5455 & 6098 & 0.89 & 952 & 16131 & 54 & 788 & 8.43 & 63.6 & 6.57 & 52.6 & 43.1 \\
\hline 26 & $\mathrm{C}$ & 5061 & 6488 & 0.78 & 812 & 13604 & 80 & 1057 & 6.28 & 56.6 & 10.5 & 56.7 & 54.6 \\
\hline 28 & C & 5182 & 6119 & 0.85 & 258 & 15562 & 101 & 1320 & 9.84 & 59.3 & 16.1 & 66.7 & 77.7 \\
\hline 30 & $\mathrm{C}$ & 5160 & 6896 & 0.75 & 828 & 14483 & 113 & 1681 & 7.33 & 63.1 & 21.0 & 81.0 & 85.9 \\
\hline 42 & C & 4536 & 6408 & 0.71 & 623 & 14973 & 97 & 1250 & 6.17 & 59.6 & 17.2 & 77.6 & 78.7 \\
\hline 44 & $\mathrm{C}$ & 4676 & 7113 & 0.66 & 735 & 14912 & 141 & 1975 & 11.1 & 65.6 & 7.43 & 84.4 & 93.3 \\
\hline 46 & A & 7016 & 6612 & 1.06 & 933 & 19867 & 127 & 1808 & 12.1 & 65.5 & 9.52 & 76.6 & 82.9 \\
\hline 48 & A & 7122 & 7055 & 1.01 & 2210 & 9360 & 163 & 1720 & 36.9 & 65.1 & 13.5 & 71.2 & 73.1 \\
\hline 50 & A & 7820 & 6860 & 1.14 & 2879 & 11636 & 96 & 1005 & 10.1 & 55.5 & 11.9 & 38.9 & 49.1 \\
\hline 52 & A & 5961 & 8582 & 0.69 & 1429 & 18171 & 159 & 2117 & 0.87 & 73.6 & 13.4 & 68.2 & 101.9 \\
\hline 54 & A & 4781 & 8070 & 0.59 & 4463 & 12024 & 135 & 1820 & 3.63 & 73.6 & 17.6 & 112.8 & 83.1 \\
\hline 56 & A & 4796 & 8678 & 0.55 & 4059 & 12265 & 99 & 939 & 8.69 & 72.9 & 12.5 & 45.0 & 48.0 \\
\hline 58 & A & 4634 & 9549 & 0.48 & 4342 & 8526 & 210 & 2374 & 7.78 & 47.1 & 15.3 & 125.3 & 107.5 \\
\hline 60 & A & 4798 & 9498 & 0.51 & 3582 & 13309 & 267 & 3461 & 10.3 & 73.8 & 34.2 & 102.1 & 132.5 \\
\hline 62 & A & 3735 & 12577 & 0.30 & 2880 & 12660 & 491 & 4984 & 13.6 & 57.3 & 61.5 & 183.9 & 198.9 \\
\hline
\end{tabular}

${ }^{a}$ Number represents metres from starting point of transect; 0 is at Fire Road and 62 is at oak-grassland boundary.

others, in decreasing order, were nickel, calcium, potassium, copper, chromium, zinc, cobalt, iron, and manganese (percentage clay, RWC, EC, and $I$ not included in this analysis owing to incomplete data). Table 11 provides a summary of the classification of results of discriminant function analysis for the soils from Jasper Ridge. Discriminant function analysis of plant tissue elemental content proved equally effective $(P<0.0001)$ in discriminating between the two races. Sodium, magnesium, and the calcium:magnesium ratio were the best discriminating variables followed by aluminum and calcium with the rest of the elements being comparatively less so. Table 12 summarizes the discriminant function analysis for plant tissue samples from Jasper Ridge.

Discriminant function analysis of soil and plant tissue variables from the other populations also indicated that both soils and plant tissue are highly reliable predictors of the two races [centroids significantly different $(P<$ $0.0001)]$.

The final treatment to which the Jasper Ridge data were subjected involved principal components analysis, the results of which are illustrated in Fig. 8a and b. Figure 8 a shows the array of sites for all soil variables. Axis 1 accounts for $32.6 \%$ of the total variation, and axis 2 accounts for $20.6 \%$. The ellipses indicate $95 \%$ confidence limits. Figure $8 \mathrm{~b}$ represents the variation for all plant tissue variables where axis 1 represents $41.3 \%$ and axis 2 , $20.3 \%$ of total variation. Again, the ellipses represent 95\% confidence limits.
Germination and growth studies - Achenes of race C plants germinated about equally in type C soil $(80 \%)$, in type A soil $(68 \%)$, and in potting soil $(83 \%)(P>0.05)$. Although the overall germination success was lower with race $\mathrm{A}$ achenes, they also germinated about equally in the three soils, $34 \%$ in type C soil, $28 \%$ in type A soil, and $38 \%$ in potting soil $(P>0.05)$. Germination results are given in Table 13.

Whereas germination behavior of achenes from the two races was about equal in the three soil types, differences in survivorship were clearly evident. Race C plants survived equally well in type $\mathrm{C}$ soil and in potting soil $(P>0.05)$, but significantly $(P<0.001)$ poorer in type A soil. At the end of the test period, $60 \mathrm{~d}$ after emergence of the radicle, $78 \%$ of race $\mathrm{C}$ plants had survived in soil normally harboring race $\mathrm{C}$ plants, whereas only $6 \%$ had survived in type A soil. The results of this experiment are illustrated in Fig. 9a.

A parallel experiment tested the capacity of race A plants to survive in the three soils. Survivorship of race A plants was not significantly different $(P>0.05)$ when reared in type C (8\%) or type A soil (10\%). Race A plants survived significantly better $(P<0.001)$ in potting soil than in either of the natural soils. These results establish that race A plants are capable of maintaining a low but similar level of survivorship in their own soil type or in soil normally associated with race $\mathrm{C}$ plants. These observations are illustrated in Fig. 9b.

Both race $\mathrm{A}$ and race $\mathrm{C}$ plants grew significantly taller 

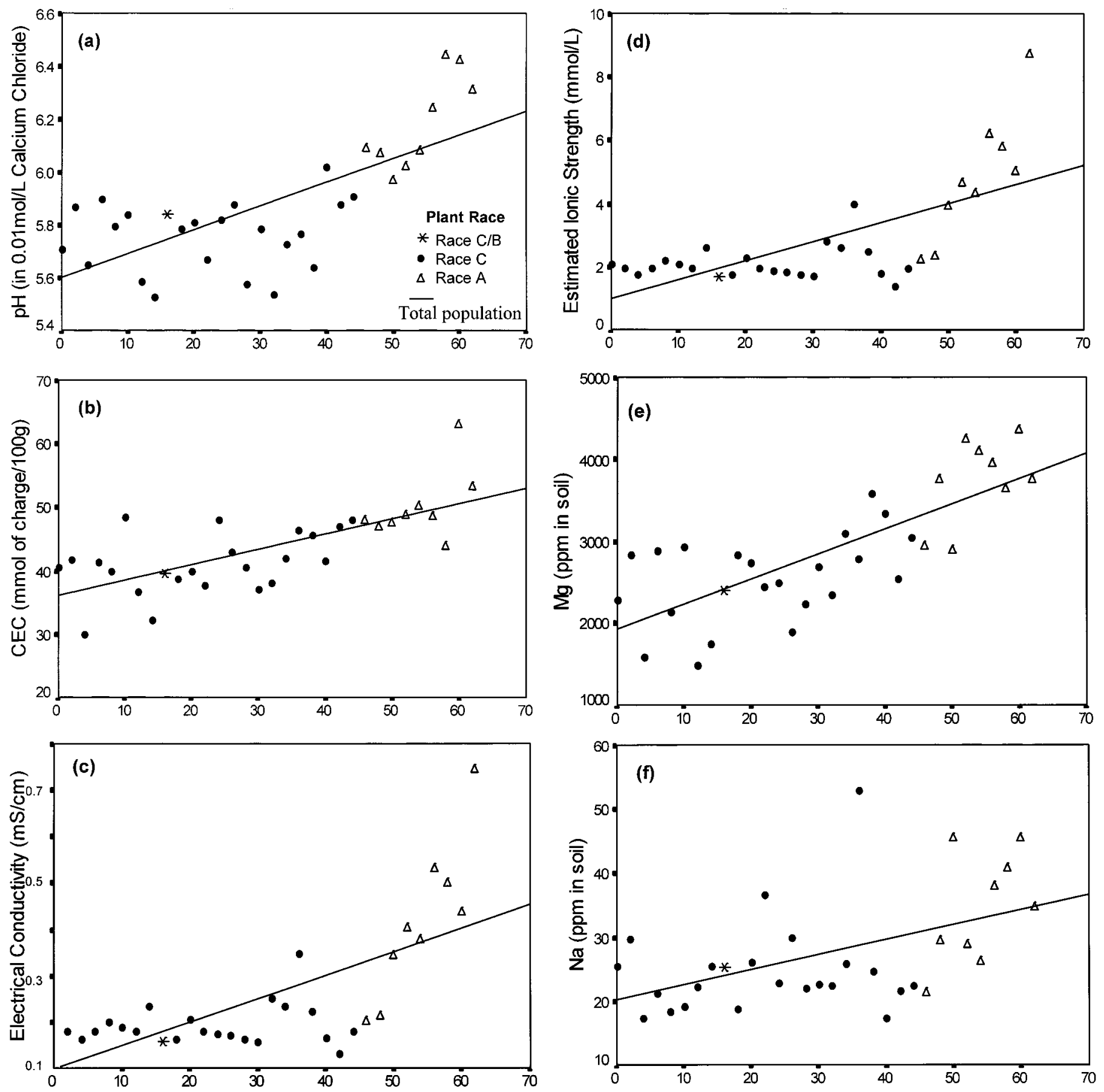

Fig. 5. Variation in soil characteristics as a function of distance along transect 3. (a) pH, (b) cation exchange capacity, (c) electrical conductivity, (d) ionic strength, (e) magnesium, (f) sodium, (g) potassium, (h) calcium, and (i) calcium:magnesium ratio.

when grown in potting soil than they did when grown in either of the natural soils. Soil normally associated with race $\mathrm{C}$ plants was the next better medium. Table 14 summarizes results from a study of height of plants maintained in the three soil types. It is clear from these observations that life in type A soil seems harsh for both races as indicated by their stunted growth. Whereas soil type does not appear to have any significant effect upon germination, as described above, further growth, demonstrated by the measurements of plant height, is clearly affected. This is also borne out in the number of leaves produced by the two races depending upon soil treatment. Table 15 shows that race A plants produce the same number of leaves when grown in type A soil or type C soil (potting soil is again the best medium). It would appear, however, that race $\mathrm{C}$ plants find life in type $\mathrm{A}$ soil to be more difficult, producing a little more than four leaves, than life in their own soil type where they produce slightly over seven leaves during the same growth period. Potting soil continues to be the best medium. Although this 

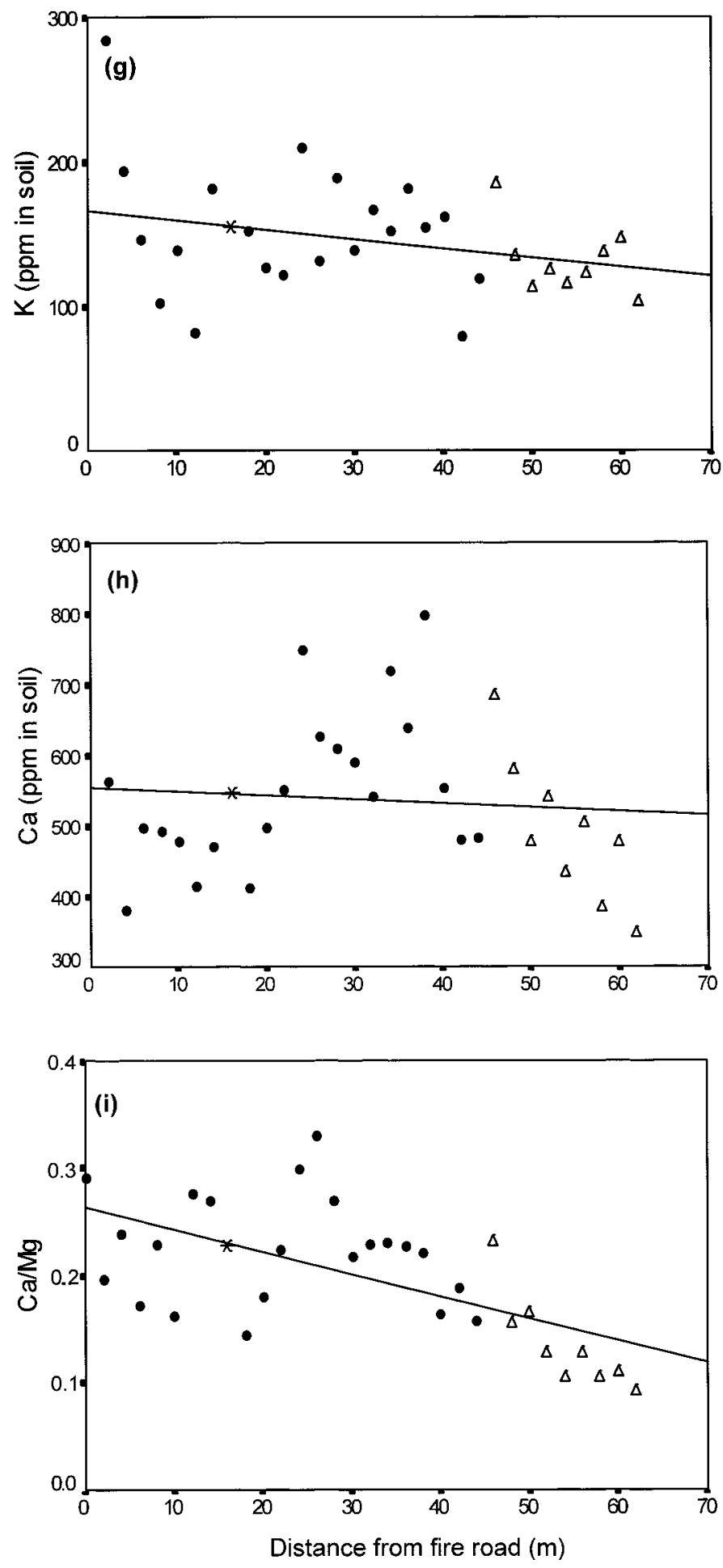

Fig. 5. Continued.

soil was not fertilized, it appears to be chemically and physically more suited for plant growth than either of the serpentine soils.

With information on hand concerning germination and growth, we next monitored the production of flower heads by the two races, again subjected to the three soil treatments. Race $\mathrm{C}$ plants in both type $\mathrm{C}$ soil and potting soil began to flower $9 \mathrm{~d}$ prior to race A plants, thus confirming the flowering time differences we had observed in the field. The most striking result came from the observation that, while race $\mathrm{C}$ plants germinated and grew in type A soil, they failed to flower. In their own soil type, some $72 \%$ of race $\mathrm{C}$ plants flowered $(P<0.0001)$. Race A plants exhibited about the same level of flowering regardless of the type of natural soil in which they were grown, $12.5 \%$ when grown in type C soil, $14.3 \%$ when grown in their own type $(P>0.05)$. When grown in potting soil both races flowered well, $63 \%$ for race A plants and almost $95 \%$ for race $\mathrm{C}$. These results are presented in Table 16.

These observations suggest that type A soil provides less than ideal growing conditions regardless of the seed source. The particular nature of the stressing factors, whether based on soil chemistry, the physical properties of the soil, or some combination thereof cannot yet be defined.

Germination and growth using soil extracts-The first set of results from this study is presented in Table 17, which shows that race A achenes germinate about equally well regardless of the nature of the irrigating solution $(P>0.05)$. On the other hand, race $C$ achenes showed a distinct sensitivity to the nature of irrigating solution, with $\sim 80 \%$ germination with an extract from its own soil type, or distilled water, but only $\sim 62 \%$ when irrigated with solution from type A soil $(P<0.005)$.

After $2 \mathrm{wk}$, the number of leaves that had developed was scored. Approximately $30 \%$ of plants developing from race $\mathrm{A}$ achenes exhibited leaves regardless of the nature of the irrigating solution $(P>0.05)$. Two-thirds of the achenes from race $\mathrm{C}$ plants developed leaves when irrigated with either extract from type $\mathrm{C}$ soil or with distilled water, whereas only $\sim 40 \%$ of $\mathrm{C}$ achenes treated with type A soil extract developed leaves $(P<0.002)$. These results are presented in Table 18.

Seed bank study-Many species characteristic of the serpentine outcrop emerged during the first month of the study. Trays containing soils from the lower part of the transect showed a lower species composition than trays containing soils from the upper part. Bottom soils were dominated by a species of Trifolium, and two species of Poa were observed. No Lasthenia seedlings appeared. Emerging from upper soils were Plantago erecta Morris, Layia platyglossa (F. \& M.) Gray, Brodiaea spp., Eschscholzia californica Cham., Castilleja sp., and three grasses. One L. californica seedling appeared. This individual, found in a tray of upper soil, was a race $C$ plant. The lack of viable achenes of $L$. californica in the seed bank indicates the importance of each year's seed fall in the establishment of a new population.

Achene dispersal-Observations on achene dispersal are also relevant. Observations in the field suggest that achenes of $L$. californica do not disperse very far. Mature inflorescences usually break at the end of the pedicel just below the receptacle bringing about $\sim 180^{\circ}$ twist, which turns the inflorescence face down. A gentle tap or current of air caused achenes to be dispersed $\sim 5-8 \mathrm{~cm}$ from the base of the mother plant with most achenes falling di- 

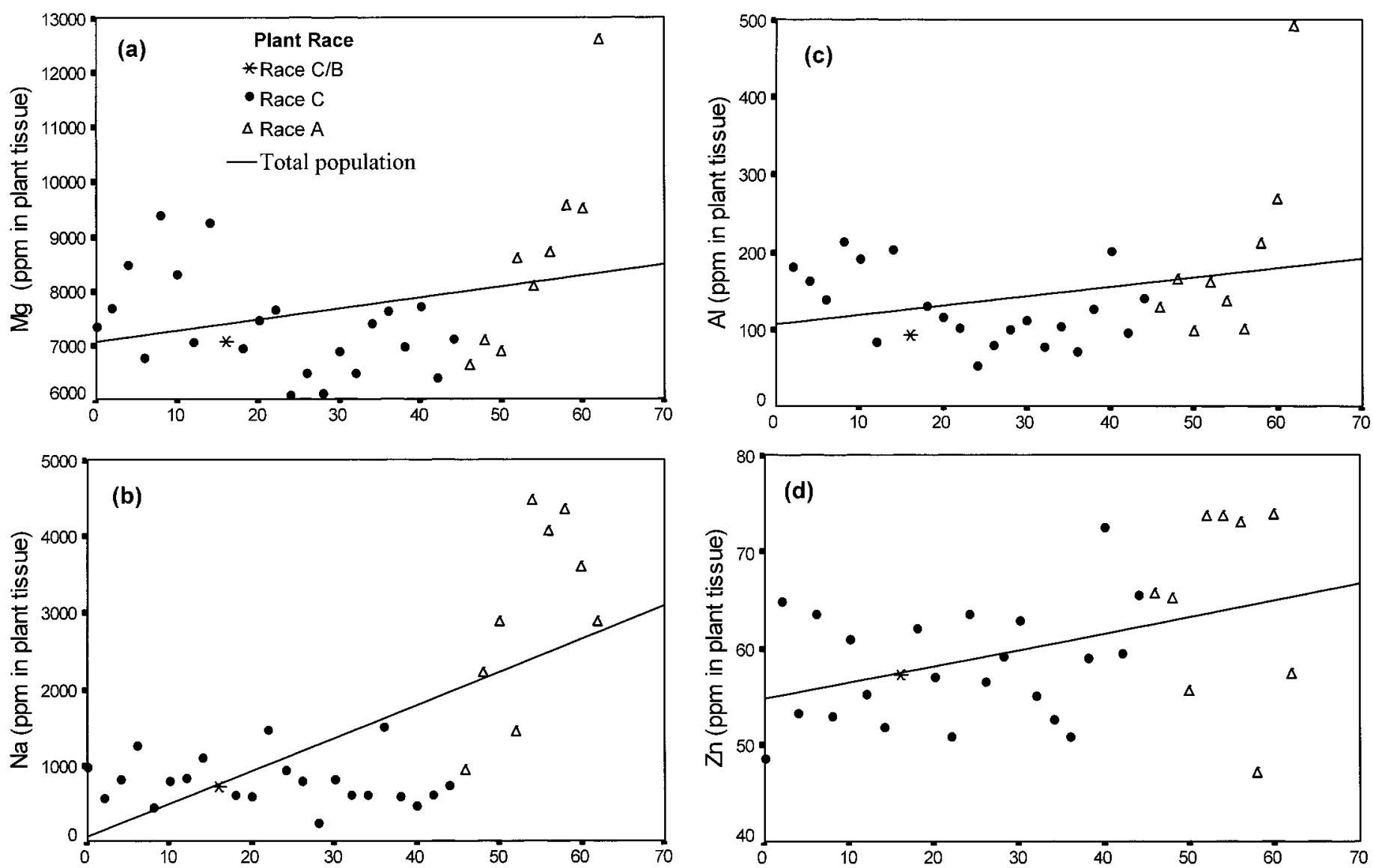

Fig. 6. Variation in plant tissue elemental composition as a function of distance along transect 3. (a) Magnesium, (b) sodium, (c) aluminum, (d) zinc, (e) potassium, (f) calcium, and (g) calcium : magnesium ratio.

rectly at the base. Achenes that do not fall directly to the ground get trapped in tufts of grass found growing adjacent to the Lasthenia plants. During the latter stage of the life cycle of $L$. californica the serpentine outcrop is usually taken over by an abundance of perennial grasses, making it difficult for the achenes to disperse far from the maternal parent.

\section{DISCUSSION}

Unusual soil conditions can give rise to localized patterns of plant distribution (Kruckeberg, 1986). The classic generalizations on the distribution of plants (Cain, 1944) place the edaphic factor second only to climate as the major environmental determinants of plant distribution. The edaphic factor pertains to the substratum upon which the plant grows and from which it derives mineral nutrients and much of its water supply, and involves physical, chemical, and biological properties of soils (Mason, 1946a, b). Soils derived from ultramafic rocks provide excellent opportunities to study the effects of the edaphic factor on plant distribution. Serpentine soils, derived from rocks such as serpentinite, are often shallow and rocky and exhibit physical and chemical properties that strongly reflect the elemental composition of their parent material. Iron, magnesium, and silicon are the major elements present with nickel, cobalt, and chromium often present in exceptional amounts. Serpentine soils have high values of exchangeable magnesium and characteristically low values of exchangeable calcium. These soils are usually deficient in nutrients such as nitrogen, phosphorus, potassium, boron, and molybdenum. They also tend to have lower clay content and their cationexchange capacities can be lower than normal (agricultural) soils; $\mathrm{pH}$ values are often high and can range from 6.1 to 8.8 (Kruckeberg, 1984, 1992; Brooks, 1987; Brady, 1990). In short, serpentine-derived soils can provide challenging, if not outright hostile, environments for the germination and successful growth of plants.

Lasthenia californica, a widespread mainly Californian spring annual, is a species capable of achieving more than mere survival in serpentine-derived soils. It can cover large areas with a dense golden floral display in early spring (giving rise to the common name "goldfields"). One of these large areas, the serpentine outcrop in the Jasper Ridge Biological Preserve of Stanford University, attracted our attention a number of years ago as an ideal site for detailed studies of flavonoid variation. In addition to the size of the population and its existence on a serpentine substrate about which comparatively little was known at the time, the site offered protection from "development," thus providing opportunity to establish a long-term program of study.

The work described in this paper involves two different, but closely related, sets of observations. The first 

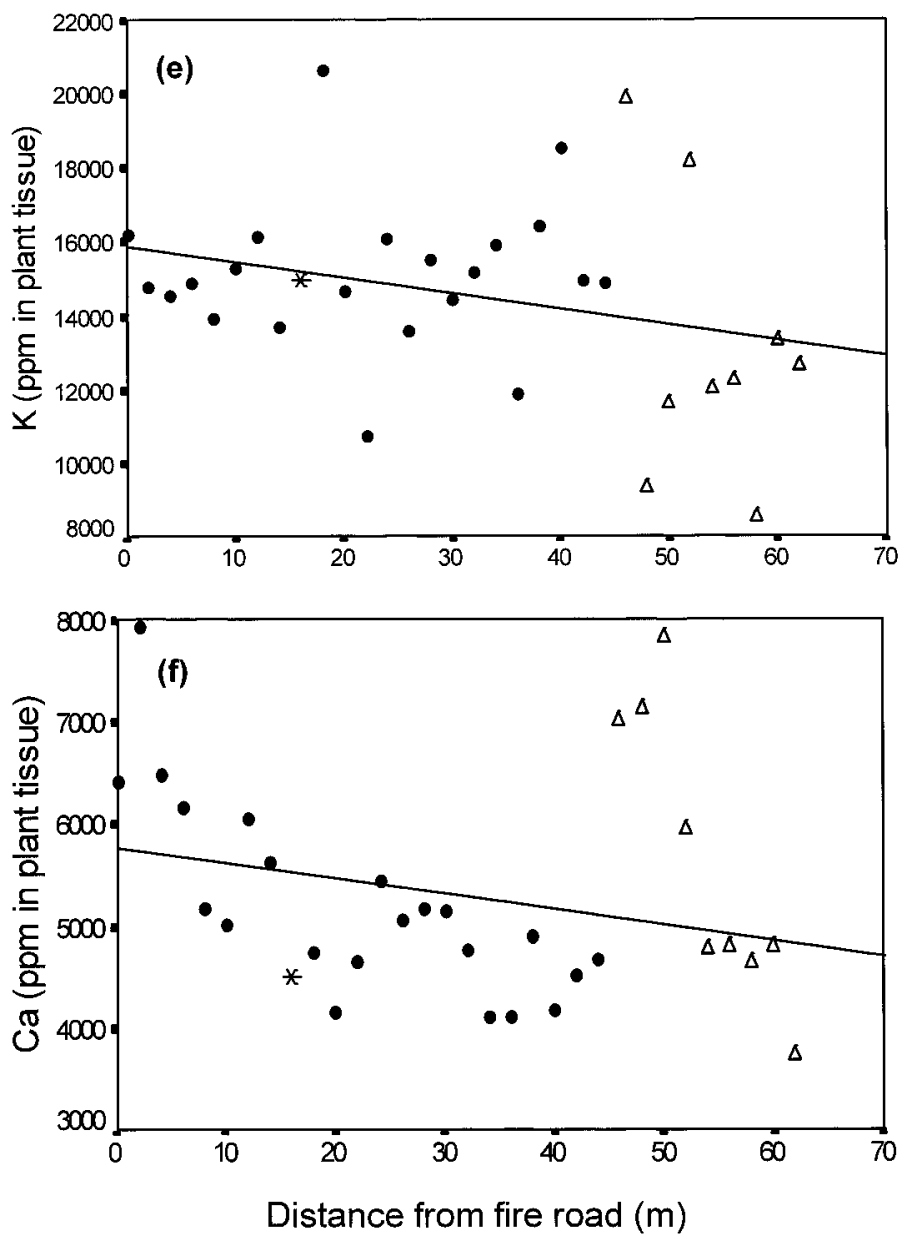

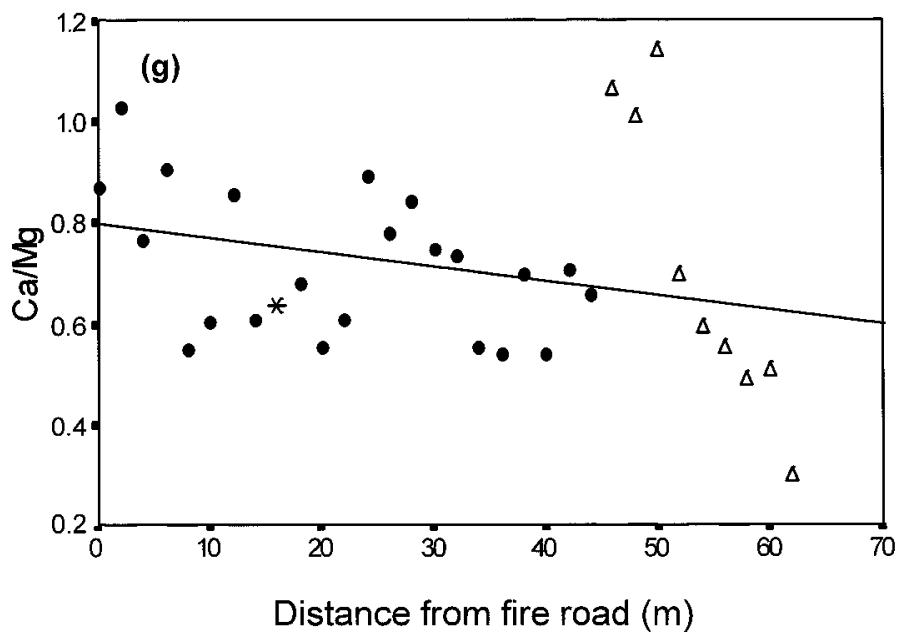

Distance from fire road $(\mathrm{m})$

Fig. 6. Continued.

involves a detailed study of soils in which the two races of $L$. californica are found and includes analysis of cation concentration, involving in turn, cation exchange capacity (CEC) and electrical conductivity (ionic strength), $\mathrm{pH}$, soil moisture content, an estimate of clay content, and observations of color and texture. Building on the descriptive information from the soil analyses, which clearly indicated differences between the two races, several experiments were run to determine the effect of soil type on germination and growth of $L$. californica. We will examine the soil chemical information first.

Our data on soil chemical and physical features for Jasper Ridge generally agree with data previously reported from Jasper Ridge (Proctor and Whitten, 1971; Turitzin, 1982; Armstrong and Huenneke, 1992; Streit, Hobbs, and Streit, 1993) and other serpentine sites in California (Kruckeberg, 1951, 1984, 1992; Woodell, Mooney, and Lewis, 1975; Fiedler, 1985; Arianoutsou, Rundel, and Berry, 1993), except for heavy metal concentrations, which were slightly lower in our hands. Reported soil concentrations of elements can often vary from study to study depending upon time and location of sampling, methods of soil collection and preparation, and method of analysis. The lower heavy metal concentrations of serpentine soils at Jasper Ridge, which we observed, may also be an indication of the poorly developed nature of these soils, reflecting the slow rate of weathering in this region. Rainfall is low and nearly absent during the summer months. Low rainfall reduces the leaching of soluble ions and slows the decay of organic matter (Streit, Hobbs, and Streit, 1993).

Analyses showed several differences in the physical and chemical properties of soils from the top of the ridge, called type $\mathrm{C}$ soils, and the bottom of the ridge, called type A soils. Type A soils are much darker, highly aggregated, and clayey in texture. The darker color suggests a higher concentration of organic matter, whereas the higher degree of aggregation is the likely result of the higher clay content. The clay fraction is likely montmorillonite (unpublished observations), which is characterized by large cracks that are often visible on the drier surfaces of these soils. Montmorillonite clays are layered structures, which allow soils to shrink when dry and swell when wet, making them physically unstable and potentially unfavorable for root growth. Soils at the bottom of the ridge are often wet and at times water-logged. In wet years race A plants have been observed growing in standing water (Bohm et al., 1989). In contrast, soils near the top of the ridge, which are populated by race $\mathrm{C}$ plants, are much lighter in color, loosely aggregated, and often quite dry.

Examination of soil characteristics along transects 
TABLE 7. Results of correlation analysis of soil and plant tissue concentrations of elements.

\begin{tabular}{llll}
\hline \hline \multicolumn{1}{c}{ Element } & $\begin{array}{c}\text { Plant } \\
\text { race }\end{array}$ & \multicolumn{1}{c}{$r$} & \multicolumn{1}{c}{$F$} \\
\hline Calcium & $\mathrm{C}$ & 0.32 & $P<0.002$ \\
Magnesium & $\mathrm{A}$ & 0.45 & $P<0.027$ \\
& $\mathrm{C}$ & 0.005 & $P>0.05$ \\
$\mathrm{Ca} / \mathrm{Mg}$ & $\mathrm{A}$ & 0.49 & $P<0.01$ \\
& $\mathrm{C}$ & 0.44 & $P<0.0001$ \\
Sodium & $\mathrm{A}$ & 0.47 & $P<0.01$ \\
& $\mathrm{C}$ & 0.253 & $P<0.015$ \\
Potassium & $\mathrm{A}$ & 0.735 & $P<0.0001$ \\
& $\mathrm{C}$ & 0.229 & $P<0.03$ \\
Iron & $\mathrm{A}$ & 1.186 & $P>0.05$ \\
& $\mathrm{C}$ & 0.119 & $P>0.05$ \\
Copper & $\mathrm{A}$ & 0.005 & $P>0.05$ \\
& $\mathrm{C}$ & 0.008 & $P>0.05$ \\
Manganese & $\mathrm{A}$ & 0.077 & $P>0.05$ \\
& $\mathrm{C}$ & 0.031 & $P>0.05$ \\
Chromium & $\mathrm{A}$ & 0.155 & $P>0.05$ \\
& $\mathrm{C}$ & 0.065 & $P>0.05$ \\
Nickel & $\mathrm{A}$ & 0.207 & $P>0.05$ \\
& $\mathrm{C}$ & 0.014 & $P>0.05$ \\
Zinc $^{*}$ & $\mathrm{~A}$ & 0.078 & $P>0.05$ \\
& $\mathrm{C}$ & 0.08 & $P>0.05$ \\
& $\mathrm{~A}$ & 0.076 & $P>0.05$ \\
\hline & & &
\end{tabular}

${ }^{\text {a }}$ Linear model; others determined using the power model.

from higher sites to lower, indicated that the bottom soils have a higher relative water content (RWC), higher $\mathrm{pH}$, greater cation exchange capacity (CEC), and higher electrical conductivity (ionic strength) than soil from nearer the top of the ridge. Concentrations of several elements increase gradually from higher to lower sites along the transects. This gradual increase in certain soil features may result from the drainage pattern with much of the leached materials ending up in the swale occupied by race A plants. The electrical conductivity (ionic strength) measurements suggest a high solute concentration in the soil solution at the bottom end of the transect, which could well provide an osmotically challenging environment for plants growing in that part of the serpentine outcrop.

Values for plant tissue concentrations of various elements at Jasper Ridge generally fall within the range of values recorded for serpentine plants (Proctor and Whitten, 1971; Woodell, Mooney, and Lewis, 1975; Fiedler, 1985; Arianoutsou, Rundel, and Berry, 1993; Kruckeberg and Reeves, 1995). Regression analysis between soil and plant tissue concentrations of various elements indicated that neither race takes up heavy metal cations in proportion to their concentrations in the soil. This behavior suggests that the two races may have exclusion mechanisms to deal with potentially toxic levels of heavy metals in serpentine soils. Unlike certain serpentine plants that deal with heavy metal environments by hyperaccumulation (Brooks, 1987; Kruckeberg and Reeves, 1995; Boyd and Martens, 1998), L. californica does not sequester unusually high levels of these elements. Regression analysis also suggests that the two races may have differential responses to certain elements in the soil. Of particular interest are magnesium, potassium, and sodium. Results indicate that race $\mathrm{C}$ plants maintain relatively constant magnesium and sodium concentrations in their tissues, whereas race A plants accumulate both of these ions in proportion to their concentrations in soil. In contrast, race C plants show a significant positive correlation between soil and tissue concentrations of potassium. No such correlation was observed in race A plants.

Analyses of soil and plants from sites other than Jasper Ridge indicated patterns that were in general agreement with those recorded for soils and plants from Jasper Ridge. Race A plants were often found in soils with higher pH, CEC, electrical conductivity (ionic strength), percentage clay, and magnesium and sodium concentrations than race $\mathrm{C}$ plants. Similarly, the calcium : magnesium ratio and potassium ion concentration were higher for soils harboring race $\mathrm{C}$ plants. Plant tissue analyses indicated that race A plants contained higher concentrations of sodium and magnesium, thus showing a pattern similar to that seen for plants at Jasper Ridge. However, unlike the
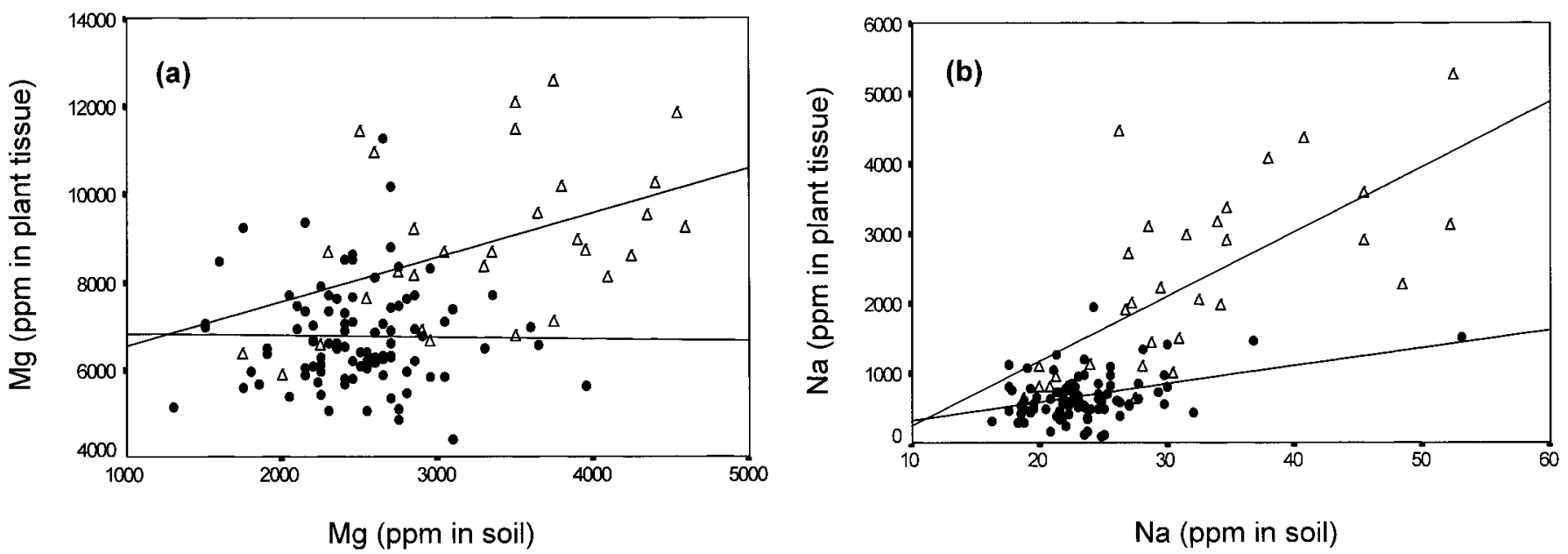

Fig. 7. The linear relationship between soil and plant tissue concentrations of (a) magnesium Race $\mathrm{C}-r=0.017$; $\mathrm{y}=-0.044 x+6888.32$ and $\triangle$ Race $\mathrm{A}-r=0.435^{*} \mathrm{y}=1.014 x+6524.55$. (b) sodium Race $\mathrm{C}-r=0.384 * ; \mathrm{y}=26.05 x+64.21$ and $\triangle \mathrm{Race} \mathrm{A}-r=0.683 * ; \mathrm{y}=$ 92.52x + 658.23. $r$ values with $*$ indicate significance at $P<0.05$. 
TABLE 8. Soil characteristics for 22 populations of $L$. californica other than Jasper Ridge. Elemental composition is given in $\mu \mathrm{g} / \mathrm{g}$ soil (ppm).

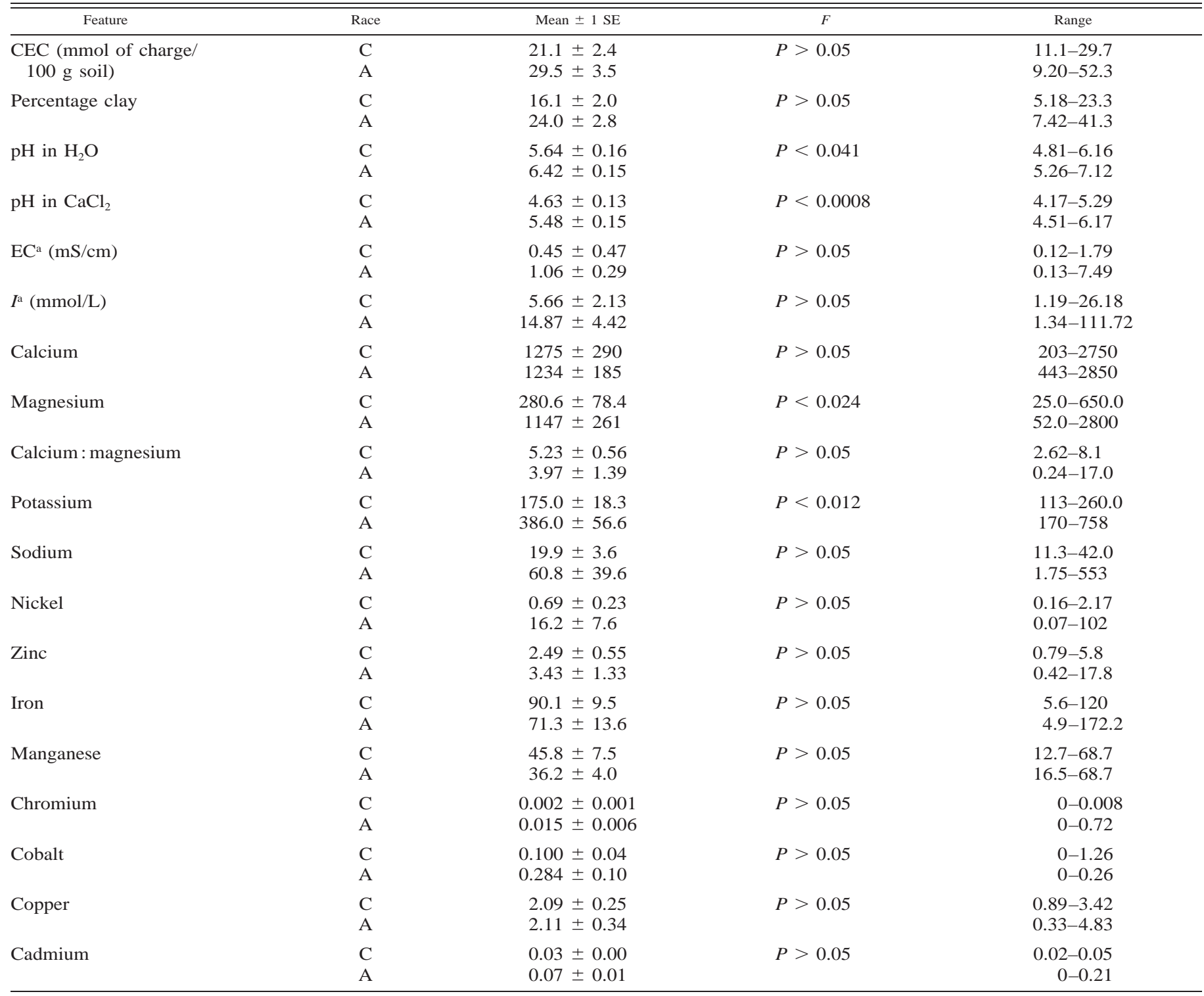

${ }^{a}$ EC and $I$ values are based on analyses of soil samples from a total of 37 populations. Included are 15 additional samples collected in 1998 from coastal bluffs, serpentine outcrops, and a vernal pool (13 race A and 2 race C). Approximate locations of these new populations are indicated in Fig. 1.

situation at Jasper Ridge most means for the two races were not statistically significantly different. This was possibly the result of the smaller sample size and the high variation in the range of values from within each race. The high within-group variation may be partly due to comparing samples growing on a variety of geologic substrates. Sodium, however, was again of special interest. Regression analysis indicated that race A plants had a much higher positive correlation for soil and plant tissue sodium than race $\mathrm{C}$ plants. A more efficient sodium uptake system in race A plants may explain why racial differentiation in this species has resulted in the ability of race A plants to colonize areas subject to water stress, be they coastal, desert, or characterized by more highly concentrated soil solutions such as those found at Soda Lake and at the bottom of the serpentine outcrop at Jasper Ridge.

Sodium is of particular interest because of the different accumulation behavior observed for the two races. Although both race $\mathrm{A}$ and race $\mathrm{C}$ plants grow in soils of roughly similar sodium ion concentrations, race A plants accumulate sodium to at least three times the concentration observed for race $\mathrm{C}$ plants. The level of sodium in race A plants approximates that found in halophytes and desert plants exposed to extreme water stress (Ravetta, McLaughlin, and O'Leary, 1997). The mechanism of accumulation of sodium ion and the significance of its accumulation in terms of survival value for the race A plants requires additional detailed study but some speculation is in order, especially in view of differences in 
TABLE 9. Elemental analysis of plant tissue for samples from 22 populations other than Jasper Ridge. Concentration of elements is given in $\mu \mathrm{g} / \mathrm{g}$ dry mass (ppm).

\begin{tabular}{lcclc}
\hline \hline Element & Race & Mean $\pm 1 \mathrm{SE}$ & $F$ & Range \\
\hline Calcium & $\mathrm{C}$ & $12473 \pm 527$ & $P>0.05$ & $1390-15890$ \\
& $\mathrm{~A}$ & $10844 \pm 1150$ & & $5371-17602$ \\
Magnesium & $\mathrm{C}$ & $2715 \pm 108$ & $P>0.05$ & $2338-3258$ \\
& $\mathrm{~A}$ & $3707 \pm 268$ & & $2019-7652$ \\
Ca/Mg & $\mathrm{C}$ & $4.62 \pm 0.19$ & $P>0.05$ & $3.80-5.37$ \\
& $\mathrm{~A}$ & $3.86 \pm 0.73$ & & $0.70-8.03$ \\
Potassium & $\mathrm{C}$ & $20424 \pm 11100$ & $P>0.05$ & $14640-24640$ \\
& $\mathrm{~A}$ & $17960 \pm 1628$ & & $227-29560$ \\
Sodium & $\mathrm{C}$ & $358 \pm 21.9$ & $P>0.05$ & $270-460$ \\
& $\mathrm{~A}$ & $547.5 \pm 232$ & & $120-3830$ \\
Nickel & $\mathrm{C}$ & $5.72 \pm 1.02$ & $P>0.05$ & $3.18-12.4$ \\
& $\mathrm{~A}$ & $11.4 \pm 3.8$ & & $1.66-56.6$ \\
Aluminum & $\mathrm{C}$ & $2426 \pm 397$ & $P<0.0001$ & $73.4-2117$ \\
& $\mathrm{~A}$ & $585 \pm 134$ & & $527-3551$ \\
Zinc & $\mathrm{C}$ & $71.7 \pm 9.3$ & $P>0.05$ & $40.6-112.5$ \\
& $\mathrm{~A}$ & $61.1 \pm 3.5$ & & $35.4-83.7$ \\
Iron & $\mathrm{C}$ & $1829 \pm 333$ & $P<0.011$ & $57.0-2992$ \\
& $\mathrm{~A}$ & $876 \pm 173$ & & $28.0-2843$ \\
Manganese & $\mathrm{C}$ & $283 \pm 49$ & $P<0.0001$ & $118-556$ \\
& $\mathrm{~A}$ & $74.1 \pm 10.4$ & & $28.9-157$ \\
Chromium & $\mathrm{C}$ & $8.18 \pm 1.66$ & $P>0.05$ & $2.15-21.2$ \\
& $\mathrm{~A}$ & $7.05 \pm 2.14$ & & $0.92-21.7$ \\
Copper & $\mathrm{C}$ & $11.1 \pm 0.5$ & $P<0.033$ & $9.35-13.4$ \\
& $\mathrm{~A}$ & $9.34 \pm 0.5$ & & $6.71-14.2$ \\
\hline
\end{tabular}

TABLE 10. Results of correlation analysis of soil and plant tissue concentration of elements for 22 populations other than Jasper Ridge.

\begin{tabular}{lcll}
\hline \hline \multicolumn{1}{c}{ Element } & $\begin{array}{c}\text { Plant } \\
\text { race }\end{array}$ & $r$ & \multicolumn{1}{c}{$F$} \\
\hline Calcium & $\mathrm{C}$ & 0.36 & $P>0.05$ \\
& $\mathrm{~A}$ & 0.78 & $P<0.024$ \\
Magnesium & $\mathrm{C}$ & 0.31 & $P>0.05$ \\
Ca/Mg & $\mathrm{A}$ & 0.81 & $P<0.0004$ \\
& $\mathrm{C}$ & 0.91 & $P<0.0001$ \\
Sodium & $\mathrm{A}$ & 0.94 & $P<0.0001$ \\
& $\mathrm{C}$ & 0.23 & $P>0.05$ \\
Potassium & $\mathrm{A}$ & 0.87 & $P<0.0001$ \\
& $\mathrm{C}$ & 0.35 & $P>0.05$ \\
Iron & $\mathrm{A}$ & 0.23 & $P>0.05$ \\
Copper & $\mathrm{C}$ & 0.22 & $P>0.05$ \\
& $\mathrm{~A}$ & 0.13 & $P>0.05$ \\
Manganese & $\mathrm{C}$ & 0.01 & $P>0.05$ \\
& $\mathrm{~A}$ & 0.08 & $P>0.05$ \\
Chromium & $\mathrm{C}$ & 0.53 & $P>0.05$ \\
& $\mathrm{~A}$ & 0.49 & $P>0.05$ \\
Nickel & $\mathrm{C}$ & 0.69 & $P=0.058$ \\
& $\mathrm{~A}$ & 0.17 & $P>0.05$ \\
Zinc & $\mathrm{C}$ & 0.96 & $P<0.0001$ \\
& $\mathrm{~A}$ & 0.92 & $P<0.0001$ \\
& $\mathrm{C}$ & 0.16 & $P>0.05$ \\
& $\mathrm{~A}$ & 0.57 & $P<0.04$ \\
\hline
\end{tabular}

TABLE 11. Classification results from discriminant function analysis for soils from Jasper Ridge.

\begin{tabular}{lccc}
\hline \hline & & \multicolumn{2}{c}{$\begin{array}{c}\text { Predicted group } \\
\text { membership }\end{array}$} \\
\cline { 3 - 4 } Actual group & $\begin{array}{c}\text { Number of } \\
\text { cases }\end{array}$ & Race A & Race C \\
\cline { 3 - 4 } Race A & 30 & $24(80 \%)$ & $6(20 \%)$ \\
Race C & 93 & $3(3.2 \%)$ & $90(96.8 \%)$ \\
\hline
\end{tabular}

root mass observed between the two races in the field and greenhouse (data not included). Root mass of individual race A plants was consistently greater than individual race $\mathrm{C}$ plants. It is possible that race $\mathrm{A}$ plants produce a larger root mass in order to increase their capacity to absorb water. It is possible that water, although present in chemically greater amounts in the lower soils, is not as biologically readily available owing to the nature of the soil. Although the soil at the bottom of the transects is wetter, its higher clay content and more aggregated nature may combine to make water less available for uptake by race A plants. It is also possible that race A plants have intrinsically greater demand for water and that these differences reflect adaptations to meet this challenge. The increased sodium ion uptake, resulting in a more favorable osmotic situation, coupled with greater root mass could be rationalized, then, as the means resorted to by these plants to survive in the desert-like, water-stressed environment. The sodium-accumulating nature of the race A plants may help to explain how this race often successfully colonizes the coastal and desert sites that characterize the southern part of the range of $L$. californica. Studies of comparative root growth under controlled conditions are necessary (and underway) in order to assess the differences in root mass. Work is also underway to study the physiology of sodium ion uptake by the two races.

The detailed soil chemical analysis of Jasper Ridge indicated that, despite the sharp boundary between the two races of $L$. californica, there are no abrupt changes in soil chemistry along the transects. The observed changes in soil chemistry are gradual with certain elements and other soil features increasing or decreasing along each transect. Even though there were no sharply defined changes in the separately tested soil characteristics, both discriminant function analysis and principal components analysis recognized the soils associated with race $\mathrm{A}$ and race $\mathrm{C}$ plants as separate groups. It is interesting to speculate that some factor, or combination of factors, grades from higher sites on Jasper Ridge to lower sites such that a threshold condition exists near the transition point ( $\sim 45 \mathrm{~m}$ ) beyond which race $\mathrm{C}$ plants can no longer complete their life cycle (set seed). The threshold may involve the plants' sensitivity to the increasing ionic con-

TABLE 12. Classification results from discriminant function analysis for plant tissue samples from Jasper Ridge.

\begin{tabular}{lcrc}
\hline \hline & & \multicolumn{2}{c}{$\begin{array}{c}\text { Predicted group } \\
\text { membership }\end{array}$} \\
\cline { 3 - 4 } Actual group & $\begin{array}{c}\text { Number of } \\
\text { cases }\end{array}$ & Race A & Race C \\
\cline { 3 - 4 } Race A & 30 & $24(80 \%)$ & $6(20 \%)$ \\
Race C & 93 & $2(2.2 \%)$ & $91(97.8 \%)$ \\
\hline
\end{tabular}



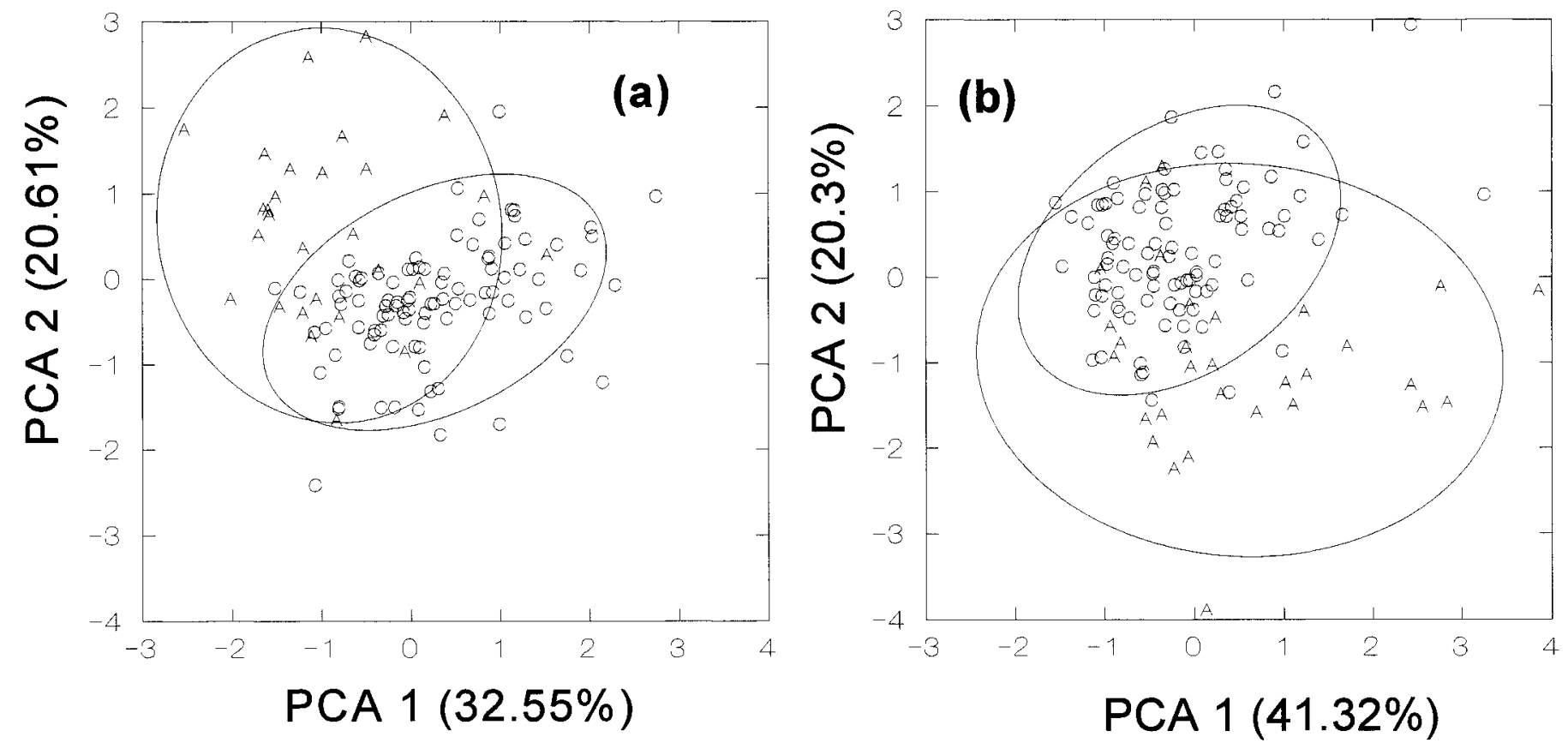

Fig. 8. Results of principal components analysis for all (a) soil and (b) plant tissue variables tested at Jasper Ridge.

centration, increasing $\mathrm{pH}$, larger concentration of clay in the soil, the differently aggregated soil, apparent aridity of the soil, or, more likely, some combination of these factors.

Many studies in the past have documented sharp boundaries in single elements, especially heavy metals, leading to vegetation boundaries over short distances (reviewed by Linhart and Grant, 1996). However, the picture at Jasper Ridge suggests that gradual increases of a number of soil characteristics, including organic substances, water content, $\mathrm{pH}$, cation exchange capacity, the cations themselves, and soil conductivity, over a short distance may have resulted in an extreme edaphic condition that is inhospitable for race $\mathrm{C}$ plants. Race A plants may be more tolerant of the extreme edaphic conditions near the bottom of the transect and are, thus, the only form that can colonize this habitat. The absence of race A plants on soils that support race $\mathrm{C}$ plants suggests that the latter are the more vigorous and outcompete the race $\mathrm{A}$ individuals near the top of the ridge. These studies suggest that no single factor can explain the pattern of occurrence of the two races on Jasper Ridge. This seems a reasonable position in view of the complexity of ecosystems that

TABle 13. Germination results for achenes of race $\mathrm{A}$ and race $\mathrm{C}$ plants of $L$. californica from Jasper Ridge.

\begin{tabular}{llccc}
\hline \hline $\begin{array}{c}\text { Plant } \\
\text { race }\end{array}$ & $\begin{array}{c}\text { Soil } \\
\text { treatment }\end{array}$ & $\begin{array}{c}\text { Percentage } \\
\text { germination } \\
\pm 1 \mathrm{SE}\end{array}$ & $F$ & Range \\
\hline Race C & type C soil & $80 \pm 3.2$ & $P>0.05$ & $76.7-90.0$ \\
& type A soil & $68 \pm 7.5$ & & $56.7-90.0$ \\
& potting soil & $83 \pm 2.4$ & & $76.7-86.7$ \\
Race A & type C soil & $34 \pm 4.6$ & $P>0.05$ & $23.3-43.3$ \\
& type A soil & $28 \pm 4.4$ & & $16.7-36.7$ \\
& potting soil & $38 \pm 3.2$ & & $33.3-46.7$ \\
\hline
\end{tabular}

function as multifactorial, holocoenotic systems (Kruckeberg, 1984). Single-factor dependence is merely a simplifying device enabling the scientist to study the system. Thus, in addition to the already demonstrated array of soil differences, it is possible that other inorganic, organic, or biotic factors (Tadros, 1957; Turkington and Aarssen, 1984; Hopkins, 1987) may differ between ridge top and bottom.

Germination and growth studies clearly indicated higher vigor of race $\mathrm{C}$ plants. This was evident from comparing germination and growth potential of both plant races in potting soil, the medium preferred by both races over either natural soil. Here, race $\mathrm{C}$ plants showed an overall higher percentage germination, survivorship, and growth than race A plants. This may be due to the naturally low vigor of race A plants or to the fact that it was not possible to provide optimal conditions for germination and growth for race A plants in the greenhouse. The patterns observed with the greenhouse studies are in some ways comparable to certain patterns observed in studies done on species pairs growing on and off serpentine (Kruckeberg, 1951, 1954, 1967), calcareous (Snaydon, 1962), and metal-contaminated sites (Cook, Lefebve, and McNeilly, 1972; Hickey and McNeilly, 1975).

TABLE 14. Height (mm) of 3-wk-old race A and race $\mathrm{C}$ plants grown in different soils.

\begin{tabular}{ccrc}
\hline \hline $\begin{array}{c}\text { Plant } \\
\text { race }\end{array}$ & $\begin{array}{c}\text { Soil } \\
\text { treatment }\end{array}$ & $\begin{array}{c}\text { Height } \\
\pm 1 \mathrm{SE}\end{array}$ & \multicolumn{1}{c}{$F$} \\
\hline Race C & type C soil & $21.24 \pm 0.62$ & $P<0.0001$ \\
& type A soil & $8.92 \pm 0.45$ & \\
& potting soil & $73.3 \pm 2.01$ & \\
Race A & type C soil & $12.6 \pm 1.2$ & $P<0.0043$ \\
& type A soil & $8.58 \pm 2.01$ & \\
& potting soil & $53.7 \pm 2.6$ & \\
& & & \\
\hline
\end{tabular}



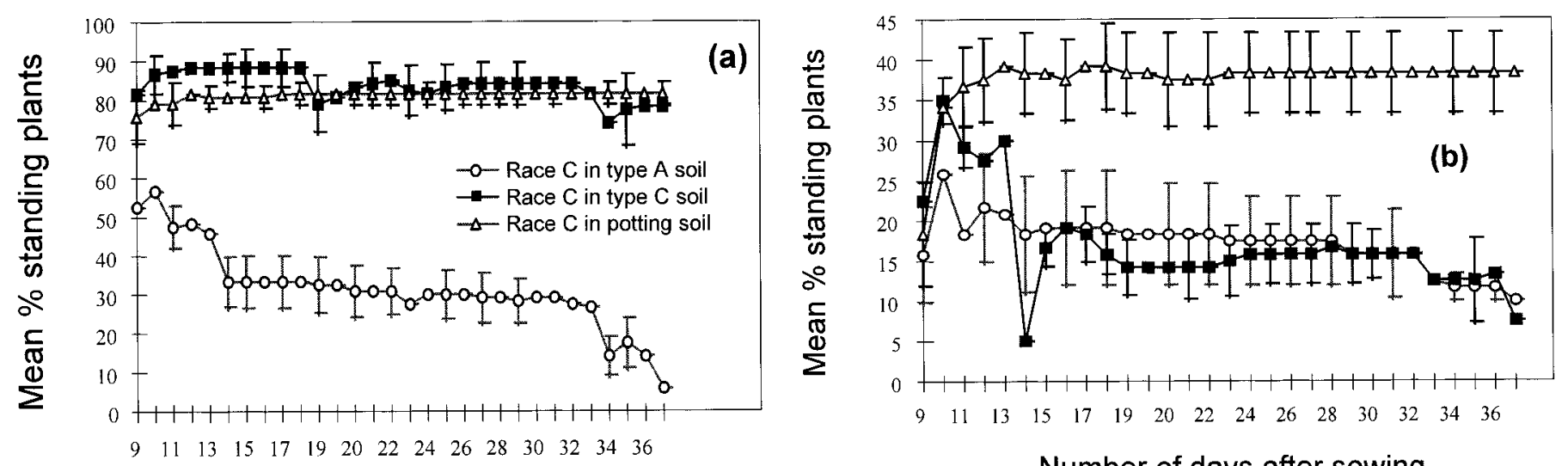

Number of days after sowing

Fig. 9. Survivorship of (a) race C and (b) race A plants in ridge top (type C soil), bottom (type A soil), and potting soils. Percentage values are based on 30 achenes per dish $\times 4$ dishes per treatment.

TABLE 15. Number of leaves in 3-wk-old race $A$ and race $C$ plants grown in different soils.

\begin{tabular}{ccrc}
\hline \hline $\begin{array}{c}\text { Plant } \\
\text { race }\end{array}$ & $\begin{array}{c}\text { Soil } \\
\text { treatment }\end{array}$ & $\begin{array}{c}\text { Number of leaves } \\
\text { per plant } \pm 1 \mathrm{SE}\end{array}$ & \multicolumn{1}{c}{$F$} \\
\hline Race C & type C soil & $7.08 \pm 0.59$ & $P<0.0001$ \\
& type A soil & $4.28 \pm 0.18$ & \\
& potting soil & $18.87 \pm 7.93$ & \\
Race A & type C soil & $4.9 \pm 0.34$ & $P<0.0001$ \\
& type A soil & $4.42 \pm 0.25$ & \\
& potting soil & $10.09 \pm 0.28$ & \\
\hline
\end{tabular}

Race A plants growing in the ridge-bottom soils are more like the "stress-tolerant" races of these previous studies, showing low vigor but an indifference to the soil in which they were grown. Race C plants best fit the "stress-intolerant" category, growing well in their own soil but poorly in the soil harboring the other race.

Ecological (extreme habitats) and physiological evidence (higher tissue sodium and greater root mass) so far documented support the possibility that race A may be a more stress-tolerant race. There is some evidence in the literature that the occurrence of sulfated flavonoids in plants seems to have some relationship to the type of habitat in which they grow (Harborne, 1975; Barron et al., 1988), occurring in plants growing under waterlogged or saline conditions. In this regard, it is interesting to note that race A plants found in coastal, desert, or serpentine soils (including the lower transect area in Jasper Ridge) contain sulfated flavonoids. This is the main

TABle 16. Percentage of race $\mathrm{A}$ and race $\mathrm{C}$ plants grown in different soils that had inflorescences $45 \mathrm{~d}$ after germination.

\begin{tabular}{cccc}
\hline \hline $\begin{array}{c}\text { Plant } \\
\text { race }\end{array}$ & $\begin{array}{c}\text { Soil } \\
\text { treatment }\end{array}$ & $\begin{array}{c}\text { Percentage of } \\
\text { plants with } \\
\text { inflorescences } \\
\pm 1 \text { SE }\end{array}$ & $F$ \\
\hline Race C & $\begin{array}{c}\text { type C soil } \\
\text { type A soil }\end{array}$ & $72.0 \pm 5.5$ & $P<0.0001$ \\
& potting soil & $94.9 \pm 1.9$ & \\
Race A & type C soil & $12.5 \pm 1.9$ & $P<0.0001$ \\
& type A soil & $14.3 \pm 1.6$ & \\
& potting soil & $63.0 \pm 5.4$ & \\
\hline
\end{tabular}

TABLE 17. Percentage of race $\mathrm{A}$ and race $\mathrm{C}$ achenes with radicle growth $8 \mathrm{~d}$ after treatment with aqueous extracts of type $\mathrm{A}$ and type C soils.

\begin{tabular}{|c|c|c|c|}
\hline $\begin{array}{l}\text { Plant } \\
\text { race }\end{array}$ & $\begin{array}{l}\text { Solution } \\
\text { treatment }\end{array}$ & $\begin{array}{l}\text { Percentage of } \\
\text { achenes with } \\
\text { radicle growth } \\
\quad \pm 1 \mathrm{SE}\end{array}$ & $F$ \\
\hline Race C & $\begin{array}{l}\text { type } \mathrm{C} \text { solution } \\
\text { type A solution } \\
\text { distilled water }\end{array}$ & $\begin{array}{l}80.0 \pm 2.7 \\
61.7 \pm 1.7 \\
76.7 \pm 4.3\end{array}$ & $P<0.005$ \\
\hline Race A & $\begin{array}{l}\text { type } C \text { solution } \\
\text { type A solution } \\
\text { distilled water }\end{array}$ & $\begin{array}{l}57.0 \pm 3.3 \\
47.0 \pm 4.7 \\
43.0 \pm 4.3\end{array}$ & $P>0.05$ \\
\hline
\end{tabular}

feature distinguishing the flavonoid profiles of the two races of L. californica. It is not clear, however, whether sulfated flavonoids play an actual role in these systems. However, experiments done on Zostera (Zosteraceae), a salt-tolerant plant, suggest that flavonoid sulfates may have an active function in salt uptake and metabolism (Nissen and Benson, 1964).

The challenges provided to plants by soils derived from ultramafic rock have been widely documented in the literature (Proctor and Woodell, 1975; Kruckeberg, 1984, 1992; Brooks, 1987). It is not unusual to see these situations described as "stressful." Yet, stress is not an easy term to define. A situation in which a plant experiences extremes of temperature, limited water, the absence of essential nutrients, or is exposed to toxic substances or high herbivore activity, can be described as stressful. Since many plants obviously have the capacity

TABLE 18. Percentage of race $\mathrm{A}$ and race $\mathrm{C}$ plants, grown on irrigated filter paper, that had leaves $14 \mathrm{~d}$ after sowing.

\begin{tabular}{cllc}
\hline \hline $\begin{array}{c}\text { Plant } \\
\text { race }\end{array}$ & $\begin{array}{c}\text { Solution } \\
\text { treatment }\end{array}$ & $\begin{array}{c}\text { Percentage of } \\
\text { plants with } \\
\text { leaves } \pm 1 \text { SE }\end{array}$ & $F$ \\
\hline Race C & type C solution & $66.7 \pm 2.7$ & $P<0.002$ \\
& type A solution & $41.7 \pm 3.2$ & \\
& distilled water & $66.7 \pm 2.7$ & \\
Race A & type C solution & $28.3 \pm 4.2$ & $P>0.05$ \\
& type A solution & $31.7 \pm 3.2$ & \\
& distilled water & $30.0 \pm 4.3$ & \\
\hline
\end{tabular}


to survive under one or a combination of these conditions, the botanist's goal is to determine how they do it. This is what we are attempting to do in the case of Lasthenia californica, some populations of which appear well adapted for living on serpentine-derived soils. Our studies have documented that two physiologically differentiated races coexist on the serpentine outcrop at Jasper Ridge-one race occupying the less stressful ridge-top soils, and the other occupying the more extreme environment at the bottom of the ridge. Plants at the bottom of the ridge exhibit adaptations normally seen in plants in water-stress situations (desert-like), much enlarged root mass, and capacity for accumulation of sodium ions. Limitation of the availability of water is likely associated with the significantly higher clay content of the ridgebottom soil. This soil also shows a greater tendency to crack, which is expected with clayey soils. Ionic toxicity (heavy metal or other) is another possibility, as indicated by growth experiments using soil extracts. The presence of toxic organic material cannot be ruled out. Both these possibilities are under investigation.

The combination of differential responses to edaphic conditions, the low level of crossability (data not included), and the markedly different flowering times strongly suggest that two different biological entities exist at the Jasper Ridge site, and by inference, across a wider range of occurrence of the species. This collection of differences, along with the restricted range of achene dispersability and the limitations of the seed bank, may contribute to maintaining the sharp boundary observed between the two races at the Jasper Ridge site. Although the racial differences discussed in this paper, combined with earlier observations on allozyme and flavonoid profiles of the two races of Lasthenia californica, would appear sufficient to address the subject of speciation, we will postpone that discussion until the study of breeding behavior, currently underway, has been completed.

\section{LITERATURE CITED}

Alva, A. K., M. E. Sumner, And W. P. Miller. 1991. Relationship between ionic strength and electrical conductivity for soil solutions. Soil Science 152: 239-242.

Arianoutsou, M., P. W. Rundel, And W. L. Berry. 1993. Serpentine endemics as biological indicators of soil elemental concentrations. In B. Markert [ed.], Plants as biomonitors. Indicators for heavy metals in terrestrial environment. VCH, Weinheim, Germany.

Armstrong, J. K., And L. F. Huenneke. 1992. Spatial and temporal variation in species composition in California grasslands: the interaction of drought and substratum. In A. J. M. Baker, J. Proctor, and R. D. Reeves [eds.], The vegetation of ultramafic (serpentine) soils. Intercept, Andover, Hampshire, UK.

Barron, D., L. Varin, R. K. Ibrahim, J. B. Harborne, and C. A. WiLliams. 1988. Sulfated flavonoids-an update. Phytochemistry 27: 2375-2395.

Black, C. A., D. D. Evans, J. L. White, L. E. Ensminger, and F. E. Clark. 1965. Methods of soil analysis. Part 2. Chemical and microbial properties. American Society of Agronomy, Inc., Madison, WI.

Bонм, B. A. 1987. Intraspecific flavonoid variation. Botanical Review 53: $197-279$.

, A. Herring, K. W. Nicholls, L. R. Bohm, and R. Ornduff. 1989. A six-year study of flavonoid distribution in a population of Lasthenia californica (Asteraceae). American Journal of Botany 76: 157-162.

$\longrightarrow$, N. A. M. Saleh, And R. ORnduff. 1974. The flavonoid chem- istry of Lasthenia (Compositae). American Journal of Botany 61: 551-561.

Boyd, R. S., AND S. N. MARTENS. 1998. Nickel hyperaccumulation by Thlaspi montanum var. montanum (Brassicaceae): A constitutive trait. American Journal of Botany 85: 259-265.

BRADY, N. C. 1990. The nature and properties of soils, 10th ed. Macmillan, New York, NY.

BROOKS, R. R. 1987. Serpentine and its vegetation: a multidisciplinary approach. Dioscorides Press, Portland, OR.

CAIN, S. A., 1944. Foundations of plant geography. Harper, New York, NY.

Cook, S. C. A., C. Lefebve, And T. McNeilly. 1972. Competition between metal tolerant and normal populations on normal soil. Evolution 26: 366-372.

DesRochers, A. M. 1992. A biosystematic study of Lasthenia californica (Asteraceae). Ph.D. dissertation, University of British Columbia, Vancouver, British Columbia, Canada.

- AND B. A. BoHM. 1993. Flavonoid variation in Lasthenia californica. Biochemical Systematics and Ecology 21: 449-453.

- AND 1 1995. Biosystematic study of Lasthenia californica (Asteraceae). Systematic Botany 20: 65-84.

FIEDLER, P. L. 1985. Heavy metal accumulation and the nature of edaphic endemism in the genus Calochortus (Liliaceae). American Journal of Botany 72: 1712-1718.

JENNY, H. 1941. Factors of soil formation, a system of quantitative pedology. McGraw Hill, New York, NY.

Harborne, J. B. 1975. Flavonoid sulfates: A new class of sulfur compounds in higher plants. Phytochemistry 14: 1147-1155.

Hickey, D. A., AND T. MCNeILly. 1975. Competition between metal tolerant and normal populations: a field experiment in normal soils. Evolution 29: 458-464.

Hopkins, N. A. 1987. Mycorrhizae in a California serpentine grassland community. Canadian Journal of Botany 65: 484-487.

KalRa, Y. P., AND D. G. MaYnard. 1991. Methods manual for forest soil and plant analysis. Information report NOR-X-319. Forestry Canada, Northwest region, Edmonton, Alberta, Canada.

KARIS, P. O., AND O. Ryding. 1994. Tribe Helenieae. In K. Bremer [ed.], Asteraceae: cladistics and classification, 521-558. Timber Press, Portland, OR.

KruckeberG, A. R. 1951. Intraspecific variability in the response of certain native plants to serpentine soil. American Journal of Botany 38: 408-419.

1954. The ecology of serpentine soils: a symposium. III. Plant species in relation to serpentine soils. Ecology 35: 267-274.

. 1967. Ecotypic response to ultramafic soils by some plant species of Northwestern United States. Brittonia 19: 133-151.

1969. Soil diversity and the distribution of plants, with examples from western North America. Madroño 20: 129-154.

. 1984. California serpentines: flora, vegetation, geology, soils, and management problems. University of California Press, Berkeley, CA.

- 1986. An essay: the stimulus of unusual geologies for plant speciation. Systematic Botany 11: 455-463.

- 1992. Plant life of western North American ultramafics. In B. A. Roberts and J. Proctor [eds.], The ecology of areas with serpentinized rock: a world view, 31-73. Kluwer Academic Publications, London, UK.

- AND R. D. REEVES. 1995. Nickel accumulation by serpentine species of Streptanthus (Brassicaceae): field and greenhouse studies. Madroño 42: 458-469.

Lindsay, W. L., AND W. A. Norvell. 1978. Development of a DTPA soil test for zinc, iron, manganese, and copper. Journal of the Soil Science Society of America 42: 421-428.

Linhart, Y. B., AND M. C. GRANT. 1996. Evolutionary significance of local genetic differentiation in plants. Annual Review of Ecology and Systematics 27: 237-277.

Mason, H. 1946a. The edaphic factor in narrow endemism. 1. The nature of environmental influences. Madroño 8: 209-226.

- 1946b. The edaphic factor in narrow endemism. 2. The geographic occurrence of plants in highly restricted patterns of distribution. Madroño 8: 241-257.

Mayer, M. S., AND P. S. Soltis. 1994. The evolution of serpentine 
endemics: a chloroplast DNA phylogeny of the Streptanthus glandulosus complex (Cruciferae). Systematic Botany 19: 557-574.

Munsell SoIl Color CharTs. 1992. Macbeth Division of Kollmorgen Instruments Corporation, revised ed. Newburgh, New York, NY.

Nissen, P., AND A. A. Benson. 1964. Absence of selenate esters and "selenolipid" in plants. Biochimica et Biophysica Acta 82: 400402.

NoRUSIS, M. J. 1993. SPSS for windows: base system user's guide release 6.0. SPSS Inc., Chicago, IL.

ORNDUFF, R. 1966. A biosystematic survey of the Goldfield genus Lasthenia (Compositae: Helenieae). University of California Publications in Botany 40: 1-92.

Page, A. L., R. H. Miller, And D. R. Keeney. 1982. Methods of soil analysis, Part 2, Chemical and microbial properties, 281-283. Soil Science Society of America, Inc. Madison, WI.

Proctor, J., AND K. WhitTEN. 1971. A population of the Valley Pocket Gopher (Thomomys bottae) on a serpentine soil. American Midland Naturalist 85: 517-521.

, AND S. R. J. WoOdELl. 1975. The ecology of serpentine soils. Advances in Ecological Research 9: 255-366.

Ravetta, D. A., S. P. Mclaughlin, and J. W. O'Leary. 1997. Evaluation of salt tolerance and resin production in coastal and central valley accessions of Grindelia species (Asteraceae). Madroño 44: $74-88$.
SNAYDON, R. W. 1962. The growth and competitive ability of contrasting natural populations of Trifolium repens $\mathrm{L}$. on calcareous and acid soils. Journal of Ecology 50: 439-447.

Streit, B., R. J. Hobbs, And S. Streit. 1993. Plant distributions and soil chemistry at a serpentine/non-serpentine boundary in California. In B. Markert [ed.], Plants as biomonitors: indicators for heavy metals in terrestrial environment. VCH, Weinheim, Germany.

TADros, T. M. 1957. Evidence of the presence of an edapho-biotic factor in the problem of serpentine tolerance. Ecology 38: 14-23.

TURITZIN, S. N. 1982. Nutrient limitation to plant growth in a California serpentine grassland. American Midland Naturalist. 107: 95-99.

Turkington, R., AND L. W. AARSSEN. 1984. Local-scale differentiation as a result of competitive interactions. In R. Dirzo and J. Sarukhan [eds.], Perspectives in plant population ecology. Sinauer, Sunderland, MA.

UBC Soil Science Laboratory Manual. 1981. Methods manual. Pedology Laboratory. Department of Soil Science, University of British Columbia, Vancouver, British Columbia, Canada.

Wilkinson, L., M. HILl, AND E. VANG. 1992. SYSTAT: statistics, version 5.2 edition. SYSTAT INC., Evanston, IL.

Woodell, S. R. J., H. A. Mooney, AND H. Lewis. 1975. The adaptation to serpentine soils in California of the annual species Linanthus androsaceus (Polemoniaceae). Bulletin of the Torrey Botanical Club 102: 232-238. 